\title{
A Systematic Review and Meta-Analysis on Catastrophic Cost Incurred by Tuberculosis Patients
}

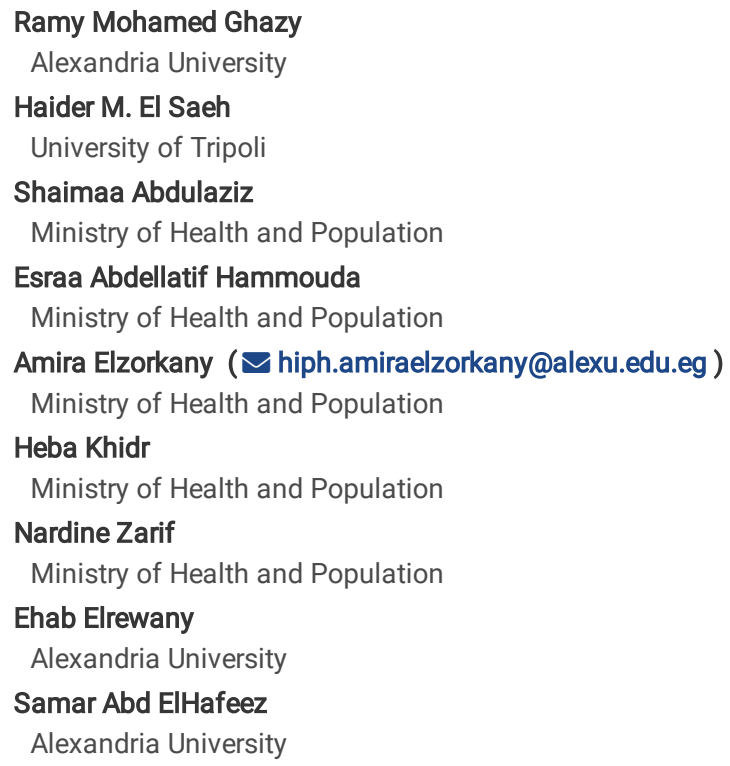

Version of Record: A version of this preprint was published at Scientific Reports on January 11th, 2022. See the published version at https://doi.org/10.1038/s41598-021-04345-x. 


\section{Abstract}

Background: One of the World Health Organization End Tuberculosis (TB) Strategy is to reduce the proportion of TB affected families facing catastrophic costs (CC) to $0 \%$ by 2020 . CC is defined if total cost related to TB management exceeded $20 \%$ of annual pre-TB household income. This study aimed to estimate the pooled proportion (PP) of TB affected households who suffered from CC.

Method: A search of the online database through September 2020 was performed. Of 5114 articles, 29 articles were included in meta-analysis. We used R software to estimate the PP at $95 \%$ confidence intervals (Cls) using the fixed/random-effect models.

Result: The PP of patients faced CC was $43 \%$. Meta-regression revealed that country, drug sensitivity and HIV co-infection were the main predictors. CC incurred by drug sensitive, drug resistant and HIV coinfection patients were $32 \%, 80 \%$, and $81 \%$ respectively. Lower CC incurred by active than passive case finding; $12 \%$ versus $42 \%$. Direct cost represented $55 \%$ ( $95 \% \mathrm{Cl} 43-66)$ of the total cost. About $45 \%$ of TB-affected household faced catastrophic health expenditure at cut-off point of $10 \%$.

Conclusion: There is still a significant proportion of TB patients facing CC, which represent a main obstacle against TB control.

PROSPERO registration: CRD42020221283

\section{Introduction}

Tuberculosis (TB) infection is one of the top 10 causes of death. It caused 1.2 million deaths in 2019. TB affects about one-quarter of the world's population[1]. According to World Health Organization (WHO) report in 2020, WHO region that reported the highest incidence of TB was Africa region $\left(266 / 10^{5}\right)$ corresponding to 2.5 million cases. The South-East Asian region ranked the second $\left(217 / 10^{5}\right)$ corresponding to 4.3 million cases followed by the East Mediterranean region $\left(114 / 10^{5}\right)$ corresponding to 819 thousand case, and by Western Pacific region $\left(93 / 10^{5}\right)$ corresponding to 1.8 million cases. On country-based ranking, number of reported new cases is the highest in India (26\%), Indonesia (8.5\%), China (8.4\%), Philippines (6.0\%), Pakistan (5.7\%), Nigeria (4.4\%), Bangladesh and South Africa (3.6\% for each) .[2]

On 26 September 2018, WHO's End TB Strategy was set and agreed by United Nation to end TB epidemic by 2030, with step wise milestones for 2020, 2025, and 2030. One of these Strategies is to reduce TB incidence rate and deaths by $90 \%$ and $95 \%$ respectively. It was also recommended to find TB missing cases by "active case finding (ACF) instead of passive case finding (PCF). ACF means systematic identification and screening of people with presumptive TB, in high-risk groups, using tests, examinations or other procedures that can be applied rapidly", while PCF entails visiting health services for diagnosis[3, 4]. In addition, all TB patients or families should not suffer from catastrophic total costs (CTC) due to TB as one of the main obstacles for TB patients to complete their treatment; [5]. Catastrophic cost is defined as the total direct and indirect costs that reaches or exceed $20 \%$ of the pretreatment patient or household's annual income. [5] of note, factors that aggravate this catastrophic cost are patient age and sex, socioeconomic status, Human immuno-deficiency virus (HIV) co-infection, and being infected with multidrug-resistant TB (MDR-TB) that does not respond to at least Isoniazid and Rifampicin, the 2 most powerful anti-TB drugs [6] [7].

The nominator of catastrophic cost is the summation of direct and indirect costs. The direct cost includes either medical cost (consultation fees, diagnostic tests and treatment) or non-medical cost (transportation, accommodation, increased food needs). Indirect cost includes lost wages due to unemployment; time spent away from work and associated loss of productivity. Moreover, patients also incur large costs in the pre-treatment phase to cover consultations and laboratory tests, symptomatic treatment, antibiotics trial, and hospitalization [8]. An important segment of the financial hardship is dissaving which means reduced financial strength of a household or engage the household in damaging financial coping strategies. This will reduce the financial capacity and their coping with the financial shocks and cast them into the poverty trap .[9] Dissaving can take many forms like taking out a loan, taking children out of education, selling assets, reducing consumption to below basic needs to cope with health-related expenditure [8-10]

Consequently, WHO developed the TB patient cost survey to properly assess the total costs and proportion of patients facing catastrophic cost. This tool provide a standardized methodology for cross-sectional surveys in TB affected countries [11]. Many studies used this cost survey to report catastrophic cost, catastrophic health expenditure, or hardship financing incurred by TB patients [12-14]. Some literatures calculated catastrophic cost for drug sensitive, MDR or HIV co-infection [14-16]. Other studies estimated compared this cost considering adoption of different case finding strategies (ACF versus PCF) [17, 18]. In response to this reported catastrophic cost, the Global TB Program endorses social protection initiatives to complement Universal health coverage (UHC) initiatives $[19,20]$. Examples of social protection interventions include cash transfers, food assistance, disability grants and health insurance. Those global financial supports already exist in most countries, but may not be fully implemented [7].

At the end, keeping in mind that COVID-19 pandemic may reverse the achieved progress in the TB control as many countries directed their resources toward pandemic containment. In addition, there are no published systematic reviews that report the pooled proportion of patients suffering from catastrophic cost; we aimed to perform this systematic review and meta-analysis to estimate the proportion of catastrophic cost among TB patients and their households in attempt to support the ongoing TB control programs.

\section{Method}

This systematic review and meta-analysis was conducted according to the Preferred Reporting Items of the Systematic Reviews and Meta-Analyses (PRISMA) guidelines [21].

Data source and search strategy

Page 2/20 
EMBASE, Scops, EBSCO, MEDLINE central/PubMed, ProQuest, Scielo, SAGE, Web of science, and Google scholar databases were searched for articles without timeframe, geographical or language restrictions up to November $20^{\text {th }}, 2020$ by two authors ( ShA \& NZ) then revised by (RMG\& SA). Highly focused and sensitive search strategies were developed by RMG after the approval of PubMed Help Disk. The search terms include ("tuberculosis "OR "Mycobacterium tuberculosis" OR "Koch's disease" AND "catastrophic cost”). References from relevant studies were screened for supplementary articles.

\section{Study selection and data extraction:}

We aimed to include observational studies, which reported the proportion of patients suffering from catastrophic cost during the intensive (first 2 or 8 months of treatment in DS or MDR respectively) or the continuation phases of TB treatment.

The primary endpoint of interest was the proportion of TB affected patients and their households who face catastrophic cost. It was defined as the total direct and indirect costs due to TB reaches or exceed $20 \%$ of the patient or household's annual income [5] . Furthermore, CTC was assessed among patients according to their drug sensitivity as DS or MDR (with or without HIV), and strategy of case finding (ACF versus PCF).

Secondary outcomes were the proportion of the direct to the total cost of TB among DS or MDR, with or without HIV, catastrophic health expenditure CHE (defined as direct cost that reaches or exceeds $40 \%$ of patients capacity to pay or $10 \%$ of their household income [22], and the different coping strategies.

Titles and abstracts were screened independently by four authors (AM, ShA, NZ, and EE), who discarded articles not pertinent to the topic. Non-observational studies, case reports, editorial, reviews, letters, and studies that estimated the direct and indirect cost of the population as a one unit not individually were excluded from qualitative analyses but screened for potential additional references. Three other authors (RMG, SA \& HE) solved the discrepancies on study judgements. Data extraction and analysis were performed by (RMG, AM, HE) and independently verified by (SA).

\section{Data analysis:}

The proportion of CTC among TB patients was pooled using the random-effects model. To ensure robustness of the model and susceptibility to outliers, pooled data was also analyzed with the fixed-effects model. Heterogeneity was assessed by the Chi-squared test on $\mathrm{N}-1$ degrees of freedom, with an alpha of 0.05 considered for statistical significance and the Cochrane-l-squared $\left(1^{2}\right)$ statistic. 12 values of $25 \%, 50 \%$ and $75 \%$ were considered to correspond to low, medium and high levels of heterogeneity, respectively.

Sources of heterogeneity, for identifying possible effect modifiers on the pooled analyses, were explored using:

1- Sensitivity analysis (leave one out sensitivity analysis, GOSH sensitivity analysis, remove outliers)

2- Subgroup analysis: we categorized the catastrophic cost at $20 \%$ for ACF and PCF patients according to country where studies were conducted (inside/outside) India.

3- Met-regression: The impact of country where the survey was conducted (high versus low incidence of TB) [23], quality of the study, sex, and population criteria (drug sensitivity, drug resistant with or without HIV) on the size effect of studies to explain the substantial heterogeneity.

The forest plot was used to visualize the degree of variation between studies. All data analysis was performed R software version 4.0 .3 using Harrer hand-on guide [24].

\section{Publication bias:}

Publication bias was investigated by visual inspection of funnel plots, and by Egger's regression test.

\section{Quality assessment}

The Newcastle-Ottawa Scale (NOS) was used to assess the quality of studies. Studies were classified according to the NOS as: very good studies (9-10 points), good studies (7-8 points), satisfactory studies (5-6 points), and unsatisfactory studies (0-4 points).[25]

\section{Results}

\section{Search results:}

The flow diagram of the selection process is shown in figure 1. In total of 5114 potentially relevant articles were found after data base search. One additional citation was found through a personal search, of this number, 1922 articles were excluded as duplicates by Endnote X8. After title and abstract screening 3041 article were excluded (201 duplicates found manually, 2840 irrelevant). Two unpublished data were included to the 152 text eligible articles to full text screening, in addition we added 2 articles were added manually. A total of 29 articles were therefore reviewed in detail and included in the analysis. The main characteristics of these studies are summarized in table 1 . The inter-rater agreement for inclusion was $\mathrm{k}=0.95$ and for the quality assessment was $\mathrm{K}=0.8$

\section{Study characteristics}

Qualitative synthesis included 29 studies conducted in 15 countries; six studies from India, five from China, four from Indonesia, one study from each of the following countries (Egypt, Zimbabwe, Nepal, Lao PDR, Ghana, Pakistan, Vietnam, Cambodia, Peru, and Cavite), and two studies from each Uganda, and South Africa. Of included studies there were 5 cohort studies [12], [13], [17], [26] \&[27] . One mixed methods study [28], while the other 23 studies were cross-sectional. Male sex presentation ranged from $30 \%$ [29], to $77 \%$ [18]. The sample size ranged from 50 [29], to 1178 [30]. The tool used for estimation of the cost survey

Page $3 / 20$ 
were either WHO TB cost survey tool, [5], [15], [30], [31], [32], [33], [34], [35], [36], [37], [38], [39], [40] \& [44], or adapted WHO tool to Indonesian context [12] \& [41], or structured questionnaire [17], [26], [42], [43], pre-coded interview scheduled [18],or tool of stop TB partnership, [13], [27], [28],or headcount tool [44], or Lumley T. survey [14], or TB coalition tool [16]. On the other hand, there were two studies not mentioned the tool used [29], [45]. The percent of patients facing catastrophic cost at cut off point $20 \%$ ranged from $4 \%$ in study of Mihir et al, study [46], to $87 \%$ in study of Wang et al, [44]. Regarding the percent of MDR-TB patients that facing catastrophic cost, they ranged from (68\%), reported by Mullerpattan 2019 to (90\%), reported by Collin et al, 2018 however DS-TB patients ranged from $24 \%$, in the study of Gadallah, 2018 to $42 \%$, in the study of Rebecca L.Walctt, 2020 . The percent of ACF patient facing catastrophic cost ranged from $9 \%$ to $44 \%$, however the percent of PCF patient ranged from $29 \%$ to $61 \%$ [18] \& [39]. Hardship financing was discussed only in two studies[14] [45]. Seven studies discussed coping cost [16], [27], [30], [33], [35], [37] \& [45]. Regarding the quality score, it was ranged from (3- unsatisfactory) [29] to (9-Very good) [34]. The Good score ranged from 7 to 8 pints, was among thirteen studies [5], [16], [17], [26], [28], [31], [32], [33], [37], [38], [39], [41] \& [45]. While Satisfactory score which ranged from 5 to 6 points, was illustrated in the remaining fourteen studies, [12], [13], [14], [15], [18], [27], [30], [35], [36], [40], [42], [43], [44] \& [45].

\section{Publication bias:}

The 29 studies reported the catastrophic cost at $20 \%$ were be assessed for the risk of bias by the funnel plot and Eggers' test [ $t=-1.188, P-v a l u e=0.24]$, which revealed the absence of asymmetry and decline the presence of publication bias. Fig. 2

\section{Primary outcome}

\subsection{Catastrophic cost at cut-off point $20 \%$}

The pooled prevalence of catastrophic cost among 11750 TB patients included in 29 studies at cut-off point of 20\% was $43 \%$ (95\% Cl:34-52) with high heterogeneity $\left(I^{2}=99 \%\right)$. Fig. (3) To identify the cause of this substantial heterogeneity we conducted meta-regression. Predictors were sex, country where the study conducted (had high incidence vs none)[23], drug sensitivity (DS or MDR \pm HIV), and quality of the study. The model was significant $P<0.0127$, $R^{2}=51.57 \%$. This model explained more than $50 \%$ of the reported heterogeneity. The identified predictors country (high vs low incidence) $(\beta=-0.194, P=0.04)$ and type of patients regarding drug sensitivity (DS or MDR) and HIV co-infection $(\beta=0.289, P=0.026)$.

In this study, there are multiple main predictors of catastrophic cost like food and nutritional supplements [33-35],travel and transportation [30, 32, 45], age category [26, 28, 32], employment status [26, 32, 36, 41, 44], the socioeconomic status[13, 26, 27, 32, 41, 44, 47], MDR or HIV positive [28, 32, 35, 47], male gender, [26, 27, 44], and duration of hospitalization $[13,28,32,44,45]$.

\subsection{Coping strategy}

In response to balance the enormous financial burden they encounter, the TB-affected families may adopt some coping strategies. Borrowing money, taking out loans, pledging gold and jewels, bringing their children out of schools or selling assets are options to compensate the income loss and the high out-ofpocket expenses [37, 45]. All these approaches are referred to as "dissaving" which is the core of the hardship financing dilemma.

\subsection{Pooled proportion of catastrophic cost at $20 \%$ among different subgroups}

\subsubsection{Pooled proportion of catastrophic cost at $20 \%$ among TB drug sensitive}

The pooled proportion of patients facing catastrophic cost was $39 \%, 95 \mathrm{Cl}(28-51 \%)$, the reported heterogeneity was $99 \%$. After removing outliers, the pooled proportion of 11 studies recruited 3492 patients dropped to $32 \%, 95 \% \mathrm{Cl}$ [29 - 35]. The pooled prevalence of DS-TB patients facing catastrophic costs ranged from $24 \%, 95 \% \mathrm{Cl}[19-30$ ] in the study of Gadallah,2018 [27] to $42 \%, 95 \% \mathrm{Cl}$ [35 - 49] in the study of Rebecca L.Walctt, 2020 [13].The heterogeneity of the included studies was as follows; $I^{2}=70 \%, P<0.01$. (Table. 2)

\subsubsection{Pooled prevalence according to TB drug resistant}

With a heterogeneity of $92 \%$, the pooled proportion of TB affected household of MDR patients facing catastrophic cost among 1879 patients was $78 \%$, $95 \% \mathrm{Cl}$, [86\%-86\%]. After removing outliers, the pooled proportion of patients facing catastrophic cost among 574 patients with MDR reached $80 \% 95 \% \mathrm{Cl}$ [74-85\%], $\mathrm{I}^{2}=54 \%$. The highest proportion (90\%) reported by Collin et al, 2018[40], while the lowest proportion (68\%) reported by Mullerpattan 2019 [29]. (Table. 2)

\subsubsection{Pooled proportion of TB-HIV co-infected patients facing catastrophic cost at $20 \%$}

The pooled proportion of 796 TB patients with HIV facing catastrophic cost at $20 \%$ was $76 \%, 95 \% \mathrm{Cl}$ [ $65-85 \%$ ], with a heterogeneity of $88 \%$. After conducting leave-one out sensitivity analysis, the study of Don Mudzengi et al 2017 [16], removed. The heterogeneity dropped to $0 \%$ and the pooled proportion patients facing catastrophic cost has increased to $81 \%, 95 \% \mathrm{Cl}[78-84]$ as it illustrated in. (Table.2)

\subsubsection{Pooled proportion of TB facing catastrophic cost at $20 \%$ through active case finding (ACF)}

The proportion of patients facing catastrophic cost among 491 patients exposed active case finding ranged from $9 \%, 95 \% \mathrm{Cl}$ [7-15\%] to $62 \%, 95 \% \mathrm{Cl}$ [45-77\%]. After subgroup analysis based on the country where the ACF was implemented (inside/outside India). The pooled proportion was $10 \% 95 \% \mathrm{Cl}[7-14 \%], \mathrm{I}^{2}=0 \%$ inside India and 48\%, 95CI(25-72\%) $\mathrm{I}^{2} 86 \%$ outside India. (Table.2)

\subsubsection{Pooled proportion of TB facing catastrophic cost through passive case finding (PCF)}


The proportion of patients facing catastrophic cost among 638 patients during passive case finding ranged from $12 \%, 95 \% \mathrm{Cl}$ [8-17\%] to $45 \%$, $95 \% \mathrm{Cl}$ [35-55\%]. The pooled proportion was $42 \%, 95 \% \mathrm{Cl}[35-50 \%]$; It is worthy to note that heterogeneity was $94 \%$. We further subdivided the studies according to the studied country (inside/outside) India. The pooled proportion of TB household facing catastrophic cost was $19 \% 95 \mathrm{Cl}(7-41 \%)$, $12=95 \%$ while outside India 45 95CI(37$53 \%$ ), $12=0 \%$. (Table.2)

\section{Secondary Outcome}

\subsection{Proportion of direct cost to the total cost}

\subsubsection{Pooled prevalence according to drug sensitive}

The proportion of the mean direct cost to the mean total cost addressed in 6 studies, the pooled proportion of direct to total cost at catastrophic cost of $20 \%$ was not calculated as the heterogeneity was high. The proportion was variants, two studies reported similar proportions, Tomeny, 2020[15] \& Collins Timire, 2020 [47] with a proportion of $41 \%$ and $43 \%$ respectively. However, higher proportion 52\% reported among Chittamany2020[33] and Nhung, 2018[37]. Two other extreme values reported, 33\% by Fuady 2018 [41] and 65\% reported by Muttamba, 2020 [30].

\subsubsection{Pooled proportion of direct cost in MDR}

The proportion of the mean direct cost to the mean total cost at 20\% addressed in 7 studies, ranged from $26 \%$ in Chittamany, 2020 [33] to $93 \%$ in Yang, 2020[32]. Low proportions were observed in Fuady, 2018[41], Tomeny, 2020 [15], and Collins Timire, 2020 [47] with proportion of 32\%, 34\% and 49\% respectively, while high proportion also reported in Muttamba, 2020[30], with 66\% and in Nhung, 2018[37] with 68\%. The pooled proportion of mean direct to total cost was difficult to assess because of the heterogeneity which wasn't explained even after a meta-regression performed.

\subsubsection{Pooled proportion of direct cost to total cost in case of active case finding (ACF)}

The pooled proportion of the mean direct cost to the mean total cost was addressed in 3 studies, the pooled proportion of mean direct to mean total cost was $25 \%, 95 \% \mathrm{Cl}[16-37 \%], \mathrm{I}^{2}=83 \%$. After conducting leave one out sensitivity analysis, the Suman Chandra Gurung, 2019 [39], was removed, the pooled proportion dropped to $29 \%, 95 \%$ C $1[20-41 \%] I^{2}=55 \%$. (Table.2)

\subsubsection{Pooled proportion of direct cost to total cost in case of passive case finding (PCF)}

The pooled proportion of the mean direct cost to the mean total cost addressed in 4 studies $[17,18,39,45]$, the pooled proportion of mean direct to mean total cost was $37 \%, 95 \% \mathrm{C} 1[31-42 \%] \mathrm{I}^{2}=0 \%$. (Table. 2 )

\subsubsection{Proportion of direct cost to total cost in case HIV and TB co-infection}

The proportion of the mean direct cost to the mean total cost addressed in 2 studies. Don Mudzengi , 2017[16] and his team showed that the proportion of mean direct cost to the mean total cost was 30\% among HIV and TB co-infection patients, while a higher proportion reported in Chittamany, 2020[33] with $59 \%$. As we couldn't pool the study because of the high un-explained heterogeneity.

The pooled proportion of the mean direct cost to the mean total cost addressed in 14 studies, the pooled proportion of mean direct to mean total cost was $55 \%, 95 \% \mathrm{Cl}[43-66 \%], \mathrm{I}^{2}=99 \%$. After conducting outliers removal, study Mihir P. Rpan, 2020 [46] was excluded, the pooled proportion dropped to $51 \%$, $95 \% \mathrm{Cl}$ [43-66\%], $\mathrm{I}^{2}=96 \%$. (Table.2)

\subsection{Catastrophic Health Expenditure at $10 \%$ \& Capacity to Pay at $40 \%$}

In this study, we have found that there are six studies that also calculated the CHE $10 \%$ and the CTP $40 \%$, in addition to their results regarding the CTC $20 \%$.

\subsection{Pooled proportion of $\mathrm{CHE}$ at $10 \%$ :}

The pooled proportion of the CHE at $10 \%$ were studied also among the studies which they calculated CTC $20 \%$. Three studies [ 2 , 27, 32] were included with pooled proportion of $45 \%, 95 \% \mathrm{Cl}[35-56 \%], \mathrm{I}^{2}=93 \%$. The result after leave one out sensitivity analysis, Fuady, 2018[40], has excluded and the heterogeneity has decreased to reach $\mathrm{I}^{2}=28 \%$, while the pooled proportion has increased to $50 \%, 95 \% \mathrm{Cl}[47-54 \%]$. (Table.2)

\subsubsection{Pooled proportion of CTP at $40 \%$ :}

With $63 \%$ pooled proportion, $95 \% \mathrm{Cl}[40-80 \%], \mathrm{I}^{2}=96 \%$, three studies measured the CTP at $40 \%[12,29,30]$ and after the sensitivity test the heterogeneity was $\mathrm{I}^{2=} 0$, while the pooled proportion increased to $70 \%, 95 \% \mathrm{Cl}[64-76 \%]$. (Table.2)

\section{Discussion}

Compared to the unknown data on the proportion of TB-patient affected household facing catastrophic cost in 2015, the GDGs goals set that 0\% of household affected by TB have faced these costs by 2020 [51]. To the best of our knowledge, this is the first article that pooled of the proportion of TB patients or their households who suffered from catastrophic cost. In this meta-analysis 29 surveys conducted in 22 countries recruiting DS-TB, MDR-TB with or without HIV recruited through ACF, PCF. The quality score of the included studies ranged from 3-10. The proportion of patients facing catastrophic cost at a cut-off point $20 \%$ was $43 \%$, $(32 \%, 95 \% \mathrm{Cl}$ [29-35] among DS and $80 \% 95 \% \mathrm{Cl}$ [74-85\%] among MDR). TB co-infected with HIV faced the highest catastrophic cost $81 \%$, 
$95 \% \mathrm{Cl}[78-84]$. Catastrophic cost was variables according to the strategy of case finding (ACF $12 \% 95 \% \mathrm{Cl}$ [9-16\%], versus PCF $42 \% 95 \% \mathrm{Cl}[35-50 \%]$ ). The direct cost including medical and non-medical cost represented $51 \%, 95 \% \mathrm{Cl}[43-59 \%]$ of the total cost. Among drug sensitive and drug resistant TB, the proportion of direct cost to the total cost ranged from $(33-65 \%)[15,30,33,37,41,47]$ and $(26 \%-93 \%)[15,30,32,33,37,41,47]$ respectively. ACF incurred lower catastrophic than PCF $29 \%, 95 \% \mathrm{C} 1$ [20-41\%] versus 37\%, 95\% C1 [34-40\%]. The direct cost to the total cost among TB and HIV co-infected patients ranged from $30 \%$ [16]-59\%[33]. The CHE was 50\%, 95\% Cl [47-54\%], and $70 \%, 95 \% \mathrm{Cl}[64-76 \%$ ] at $10 \%$ of household yearly income and $40 \%$ of their capacity to pay respectively.

\section{Catastrophic cost}

In fact, the cost incurred by some patients may be catastrophic and minimal for others. This is based on the household annual income. In the current study, we have included many studies that addressed the catastrophic cost among the TB at different thresholds, points (30\%, 25\%, 20\%, 10\% and 5\%). Despite absence of robust evidence on the sensitivity of the cut-off point at $20 \%$ to reflect the catastrophic cost regardless patients are drug sensitive or resistant. Fuady et al, [12]settled $15 \%$ and $30 \%$ as more consistent cut-of points for treatment adherence and success respectively. In the current work, the proportion of TBhousehold patients facing catastrophic cost was 39\%, which considered very high compared to the targeted GDGs in 2020 (0)\%, more efforts and activities need to be directed to reduce this cost. It is worthy to note that diagnosis and treatment are provided for free in many of the included countries under the umbrella pooled of NTP, however, the treatment related expenditure is still very high. Yadav and his group, [52] illustrated that even with free services for tuberculosis care, $21.3 \%$ of the people in their study exposed to hardship financing, advising the need to take into consideration more innovated ways to increase the supported coverage of tuberculosis treatment in the country. The study also suggests the use of hardship financing as an index to measure the effectiveness of tuberculosis control program in the country. It is crucial to decrease the burden of catastrophic cost among the TB patients as it results in poorer treatment outcome. Patients suffer from catastrophic cost had 2-4 times higher odds of treatment failure than those who do not[12]. The latter is due to reduces access to the treating health facility, and treatment completion. Turning to the coping cost, a large proportion of household's resort to different coping strategies to confront the increased out-of-pocket costs; and to compensate the consequences of income loss. Those coping strategies include selling a property or livestock, taking loans, pledging jewels, dropping their children out of school and cutting down their consumption to below basic needs [7]. Despite pooling of these studies' outcome yielded substantial heterogeneity, the current study has found that almost $51 \%$ of heterogeneity, was mainly because of two predictors, the first was that some studies estimated CTC of DS and patients with MDR with or without HIV together. This factor played a major role in the heterogeneity, as it was clear that the CTC was dramatically higher among patients with HIV. The second predictor was the classification of country where the study was conducted[23]. Two-third of the new cases of TB reported in eight countries of the world, with India foremost the count, followed by Indonesia, China, the Philippines, Pakistan, Nigeria, Bangladesh and South Africa. Consequently, we divided studies into studies conducted in countries with high versus low incidence. In meta-regression, the country, where the study was conducted was a second major determinant of the different size effect.

The reported high incidence of CTC in many countries raised the need for social protection interventions. The most common social protection intervention is the cash transfer or cash assistance; it has already implemented in many countries across the world either conditionally or unconditionally [53]. In such a way, it is supposed that the household can get better access to treatment and food. Other social protection interventions include disability grants, food baskets (food assistance), food or travel vouchers and social insurance[7]. Many countries implemented reimbursement programs to help TB patients to cope with the disease cost. However, these programs prioritize poorer and MDR[54].The effect of this intervention is questionable. At a cutoff point of $20 \%$, two studies have applied and calculated a catastrophic cost before and after reimbursement. Lue et al,2020[42] there reported a slight change on the proportion of CTC; before reimbursement, the CTC was (22\%) and declined to $19 \%$ after the reimbursement. In contrary, Fuady,2019,[55] showed a higher change in the proportion of CTC after the reimbursement. The intervention program effectively decreased CTC from $44 \%$ to $13 \%$. With regards to cash transfer, Wingfield et al, 2016 [56] reported that the proportion of TB household suffered from CTC was $30 \%$ and $42 \%$ among intervention and control respectively. These findings indicate that this social support is not enough to mitigate the impact of TB. Consequently, household of TB patients should receive sufficient financial support that covers the indirect cost (job lost), and direct cost (transportation, food, accommodation)[57].Of note, this social support should be proportionate to the income lost, this is due to the high variability of the pretreatment income. We speculate that development of newer treatment guidelines for TB of shorter duration would be beneficial. At the bottom, provision of free medication is not sufficient to prevent the catastrophic cost. TB patients should receive transport vouchers, reimbursement schemes and food assistance to reduce or compensate for such catastrophic costs. Furthermore, decentralization of patient supervision (including directly observed therapy), e.g. through community-based or workplace-based treatment [58], can reduce transport costs as well as income loss for patients[59].

As expected, the catastrophic cost among MDR was higher than DS, as DS patients receive treatment for shorter duration (6 months only), while MDR treatment extend to 24 months. Additional cost is incurred by MDR patients like the cost related to prolonged days of work absenteeism, need for daily injection, exposure to more side effects, and need for investigation [60].

\section{Direct cost to total cost}

The mean total direct cost to the mean total cost was lower than the mean indirect cost among drug sensitive patients, HIV co-infected patients, while it was higher among drug resistant patients. This finding is essential to be considered when reimbursement strategies are implemented. Stakeholders should know which part of patient cost should be compensated. The direct cost dropped significantly if the strategy of active case finding was adopted instead of the passive case finding (29\% to $37 \%)$ respectively.

\section{Determinant of catastrophic cost}

Of note, it is essential to identify the factors that contribute to catastrophic cost. In this study, there are multiple main predictors of catastrophic cost. The main two components that affect the catastrophic cost are income loss as an impact of being diseased and food and nutritional supplements other than the patients' regular diet habit addressing the catastrophic cost through increasing the direct non-medical costs [33-35]. Also travel and transportation affect the 
direct non-medical costs increasing the suffer of TB patients [30]. Age also considered to affect the prevalence of catastrophic cost whether the young age [27] or the old age [32].

\section{Catastrophic health expenditure}

Out of the 29 studies, only six studies have been included with a clear measurement of the CHE at $10 \%$ of their income and $40 \%$ of their capacity to pay. It was clear that many studies ignored $\mathrm{CHE}$, despite its importance to understand the impact of this cost on treatment outcome [42]. Two studies assessed the effect of reimbursements intervention on the CHE. Xiang et al, [61] reported a 8\% reduction in CHE, however, this reduction was not statistically significant. Similarly, Zhou et al[62] reported that the effect of reimbursement on CHE was minimal, the achieved reduction in CHE was only $12 \%$. In order to decrease the catastrophic expenditures National health financing systems must be designed and implemented, not to allow people to access services when they are needed only, but also to protect households from financial catastrophe, by reducing out-of-pocket spending. In the long run, prepayment mechanisms should be developed, for instance, social health insurance, tax-based financing of health care, or some mix of prepayment mechanisms such as efficient reimbursement or cash intervention. [63]

\section{Strength and limitation of the study}

Our study has many strengths and limitations. Strengths include a comprehensive systematic approach to the existing literature, study selection, data extraction and quality assessment that have all been conducted according to current methodological standards. Furthermore, we included all studies without design, language, or geographical restriction. Moreover, we considered an ample list of outcomes and we compared these outcomes based on the definition, drug sensitivity and HIV infection. The limitation of this study was that different cut-off points were settled by different studies to estimate the proportion of the households facing catastrophic cost using different tools. A major challenge was that different studies estimated the catastrophic cost due to TB regardless drug sensitivity (DS, MDR), co-infection with HIV, case finding strategy (ACF, and PCF). Another point of limitation was that all studies included subjects with confirmed TB. Costs for those ill patients with undiagnosed TB may add a lot to the already estimated values. Furthermore, many of the included studies used the WHO cost survey tool, that include patients only treated in the NTP, omitting patients treated in private sectors who represent a considerable proportion of TB patients.

\section{Conclusion}

About future global policy, our study provides evidence that despite the free TB treatment policy, there is a major proportion of TB patients are still facing catastrophic cost. The proportion of patient facing catastrophic cost is variable according to the type of TB; lowest among DS, higher in MDR, and highest if there is concomitant infection with HIV. Patients exposed to ACF incurred lower cost than those exposed to PCF. The direct cost (medical \&non-medical) related to TB is not the only major contributor to the catastrophic cost, indirect cost represents a major contributor that should not be ignored. To sum up, this study paves the way to effective cost mitigation in the context of the End TB Strategy. As it addressed the proportion of TB patients and their households who are suffering from catastrophic cost and its predictors. Obviously, effective management of these predictors will eventually contribute to better community, clinical, financial outcomes [64]. Now it is clear that, the global health system must do more efforts to achieve the zero catastrophic cost for TB by 2030.

\section{Declarations}

\section{Acknowledgments}

Many efforts overseas co-operate to finalize this work in this comprehensive way. We would like to thank Dr. Samia laokri and Dr. Charlesbatt, for giving us the opportunity to access their full-texts papers, which helped to make this Meta-analysis comprehensive, and guide us to the most robust outcome. Assistant Professor | Department of Instructional Technology and Learning Sciences, Otah University USA. We would like also, to express our indebtedness and deepest gratitude to Dr. Ramy shaaban, Dr. Suzan, and Dr. Ahmed Mandil (EMRO-WHO) for their great help, which enriched our search.

\section{Author contribution}

Ramy Mohamed Ghazy (RMG): Grant holder, conceptualized and designed the study, database search, full text screening, data analysis, writing manuscript.

Haider El Saeh (HE): Revision of tittle \& abstract, revision of the full text screening and data extraction, data analysis and writing manuscript.

Shaimaa Abdulaziz (ShA): Database search with full text screening, data extraction, writing manuscript and references manager.

Amira Mohamed Elzorkany (AM): Full text screening, data extraction, data analysis and writing manuscript.

Heba Khidr (HK): Database search with full text screening

Nardin Zarif (NZ): Database search with full text screening, data extraction and writing manuscript.

Esraa Abdellatif (EAH): Full text screening, data extraction and writing manuscript.

Ehab Elrewany (EE): Full text screening, data extraction and writing manuscript.

Samar Abdel-Hafeez (SA): Final decision of the title \& abstract screening with the full text screening, and writing manuscript.

Funding

Page $7 / 20$ 
This research was partially funded by WHO-TDR (SGS 20-28)

\section{Conflict of interest}

All authors have read the criteria set out in the ICMJE form, and they disclosed, there isn`t conflict of interest.

\section{References}

1. World Health Organization. 10 facts on tuberculosis. 2020 Oct 14, 20202021 Feb 20th]; Available from: https://www.who.int/news-room/facts-inpictures/detail/tuberculosis.

2. world Health Organization. Tuberculosis. 2020 [cited 2021 Feb 19]; Available from: https://www.who.int/news-room/fact-sheets/detail/tuberculosis.

3. World Health Organization, Systematic screening for active tuberculosis: principles and recommendations. 2013: World Health Organization.

4. Singh, M., et al., Are treatment outcomes of patients with tuberculosis detected by active case finding different from those detected by passive case finding? Journal of global infectious diseases, 2020. 12(1): p. 28.

5. Stracker, N., et al., Risk factors for catastrophic costs associated with tuberculosis in rural South Africa. The International Journal of Tuberculosis and Lung Disease, 2019. 23(6): p. 756-763.

6. World Health Oganization. Tuberculosis: Multidrug-resistant tuberculosis (MDR-TB). 2018 [cited 2021 Feb 19]; Available from: https://www.who.int/newsroom/q-a-detail/tuberculosis-multidrug-resistant-tuberculosis-(mdr-tb).

7. Tanimura, T., et al., Financial burden for tuberculosis patients in low-and middle-income countries: a systematic review. European Respiratory Journal, 2014. 43(6): p. 1763-1775.

8. Lönnroth, K., et al., Beyond UHC: monitoring health and social protection coverage in the context of tuberculosis care and prevention. PLoS Med, 2014. 11(9): p. e1001693.

9. Madan, J., et al., What can dissaving tell us about catastrophic costs? Linear and logistic regression analysis of the relationship between patient costs and financial coping strategies adopted by tuberculosis patients in Bangladesh, Tanzania and Bangalore, India. BMC health services research, 2015. 15(1): p. 1-8

10. World Health Organization, Global status report on alcohol and health 2018. 2019: World Health Organization.

11. World Health Organization, Tuberculosis patient cost surveys: a handbook. 2017.

12. Fuady, A., et al., Catastrophic costs due to tuberculosis worsen treatment outcomes: a prospective cohort study in Indonesia. Transactions of The Royal Society of Tropical Medicine and Hygiene, 2020.

13. Walcott, R.L., et al., There's no such thing as a free TB diagnosis: Catastrophic TB costs in Urban Uganda. Global Public Health, 2020: p. 1-12.

14. Ruan, Y., et al., The affordability for patients of a new universal MDR-TB coverage model in China. The International Journal of Tuberculosis and Lung Disease, 2016. 20(5): p. 638-644.

15. Tomeny, E., et al., Patient-cost survey for tuberculosis in the context of patient-pathway modelling. International Journal of Tuberculosis and Lung Disease, 2020. 24(4): p. 420-427.

16. Mudzengi, D., et al., The patient costs of care for those with TB and HIV: a cross-sectional study from South Africa. Health policy and planning, 2017. 32(suppl_4): p. iv48-iv56.

17. Shewade, H.D., et al., Active case finding among marginalised and vulnerable populations reduces catastrophic costs due to tuberculosis diagnosis. Global health action, 2018. 11(1): p. 1494897.

18. Muniyandi, M., et al., Catastrophic costs due to tuberculosis in South India: comparison between active and passive case finding. Transactions of The Royal Society of Tropical Medicine and Hygiene, 2020. 114(3): p. 185-192.

19. Rudgard, W.E., et al., Comparison of two cash transfer strategies to prevent catastrophic costs for poor tuberculosis-affected households in low-and middle-income countries: an economic modelling study. PLoS medicine, 2017. 14(11): p. e1002418.

20. Wingfield, T., et al., Defining catastrophic costs and comparing their importance for adverse tuberculosis outcome with multi-drug resistance: a prospective cohort study, Peru. PLoS Med, 2014. 11(7): p. e1001675.

21. Tricco, A.C., et al., PRISMA extension for scoping reviews (PRISMA-ScR): checklist and explanation. Annals of internal medicine, 2018. 169(7): p. 467-473.

22. World Health Organization, Distribution of health payments and catastrophic expenditures methodology. 2005, World Health Organization.

23. World Health Organization. Tuberculosis (TB) 2021 [cited 20216 February ]; Available from:https://www.who.int/news-room/fact-

sheets/detail/tuberculosis\#: :text=Global\%20impact\%20of\%20TB\&text=In\%202019\%2C\%2087\%25\%20of\%20new,Nigeria\%2C\%20Bangladesh\%20and\%2

24. Harrer, M., et al., Doing meta-analysis in R: a hands-on guide. PROTECT Lab Erlangen, 2019.

25. Moskalewicz, A. and M. Oremus, No clear choice between Newcastle-Ottawa Scale and Appraisal Tool for Cross-Sectional Studies to assess methodological quality in cross-sectional studies of health-related quality of life and breast cancer. Journal of clinical epidemiology, 2020. 120: p. 94-103.

26. Wingfield, T., et al., Beyond pills and tests: addressing the social determinants of tuberculosis. Clinical medicine, 2016. 16(Suppl 6): p. s79.

27. Mohsen Gadallah, W.A., Assessing household catastrophic total cost of Tuberculosis and their determinants in Egypt: A cohort prospective study, M. Ain Shams University, Editor. 2019.

28. Prasanna, T., et al., Catastrophic costs of tuberculosis care: a mixed methods study from Puducherry, India. Global health action, 2018. 11(1): p. 1477493. 
29. Mullerpattan, J.B., et al., Catastrophic costs of treating drug resistant TB patients in a tertiary care hospital in India. Indian Journal of Tuberculosis, 2019. 66(1): p. 87-91.

30. Muttamba, W., et al., Households experiencing catastrophic costs due to tuberculosis in Uganda: magnitude and cost drivers. BMC Public Health, 2020. 20(1): p. 1-10.

31. Muniyandi, M., et al., Association of Tuberculosis With Household Catastrophic Expenditure in South India. JAMA Network Open, 2020. 3(2): p. e1920973e1920973.

32. Yang, T., et al., Factors associated with catastrophic total costs due to tuberculosis under a designated hospital service model: a cross-sectional study in China. BMC Public Health, 2020. 20(1): p. 1-13.

33. Chittamany, P., et al., First national tuberculosis patient cost survey in Lao People's Democratic Republic: Assessment of the financial burden faced by TBaffected households and the comparisons by drug-resistance and HIV status. PloS one, 2020. 15(11): p. e0241862.

34. Viney, K., et al., Four of five tuberculosis patients experience catastrophic costs related to TB diagnosis and care in Timor-Leste. The International Journal of Tuberculosis and Lung Disease, 2019. 23(11): p. 1191-1197.

35. Pedrazzoli, D., et al., How affordable is TB care? Findings from a nationwide TB patient cost survey in Ghana. Tropical Medicine \& International Health, 2018. 23(8): p. 870-878.

36. Ikram, A., et al., Is Tuberculosis Treatment Truly Free? A Study to Identify Key Factors Contributing to the Catastrophic Cost of TB Care in Pakistan. Journal of Tuberculosis Research, 2020. 8(4): p. 181-198.

37. Nhung, N., et al., Measuring catastrophic costs due to tuberculosis in Viet Nam. The International Journal of Tuberculosis and Lung Disease, 2018. 22(9): p. 983-990.

38. McAllister, S.M., et al., Out-of-pocket costs for patients diagnosed with tuberculosis in different healthcare settings in Bandung, Indonesia. The American Journal of Tropical Medicine and Hygiene, 2020. 103(3): p. 1057-1064.

39. Gurung, S.C., et al., The role of active case finding in reducing patient incurred catastrophic costs for tuberculosis in Nepal. Infectious diseases of poverty, 2019. 8(1): p. 99.

40. Collins, D., et al., Can patients afford the cost of treatment for multidrug-resistant tuberculosis in Ethiopia? The International Journal of Tuberculosis and Lung Disease, 2018. 22(8): p. 905-911.

41. Fuady, A., et al., Catastrophic total costs in tuberculosis-affected households and their determinants since Indonesia's implementation of universal health coverage. Infectious diseases of poverty, 2018. 7(1): p. 3.

42. Lu, L., et al., Catastrophic costs of tuberculosis care in a population with internal migrants in China. BMC health services research, 2020. $20(1)$ : p. 1-9.

43. Xu, C.-H., et al., Inequity in catastrophic costs among tuberculosis-affected households in China. Infectious diseases of poverty, 2019. 8(1): p. 46.

44. Wang, Y., et al., Household financial burden among multidrug-resistant tuberculosis patients in Guizhou province, China: A cross-sectional study. Medicine, 2020. 99(28).

45. Morishita, F., et al., Mitigating financial burden of tuberculosis through active case finding targeting household and neighbourhood contacts in Cambodia. PloS one, 2016. 11(9): p. e0162796.

46. Rupani, M.P., et al., Costs incurred by patients with drug-susceptible pulmonary tuberculosis in semi-urban and rural settings of Western India. Infectious diseases of poverty, 2020. 9(1): p. 1-8.

47. Timire, C., et al., Catastrophic costs among tuberculosis patients in Zimbabwe: a national health facility-based survey. 2020.

48. Laokri, S., et al., Assessing the economic burden of illness for tuberculosis patients in Benin: determinants and consequences of catastrophic health expenditures and inequities. Tropical Medicine \& International Health, 2014. 19(10): p. 1249-1258.

49. Ukwaja, K.N., I. Alobu, and P.C. Hopewell, The high cost of free tuberculosis services: patient and household costs associated with tuberculosis care in Ebonyi State, Nigeria. PloS one, 2013. 8(8): p. e73134.

50. Sarin, R., et al., Identifying costs contributing to catastrophic expenditure among TB patients registered under RNTCP in Delhi metro city in India. indian journal of tuberculosis, 2019. 66(1): p. 150-157.

51. World Health Organization, Systematic screening for active tuberculosis: an operational guide. 2015: World Health Organization.

52. Yadav, J., D. John, and G. Menon, Out of pocket expenditure on tuberculosis in India: Do households face hardship financing? Indian Journal of Tuberculosis, 2019. 66(4): p. 448-460.

53. Boccia, D., et al., Towards cash transfer interventions for tuberculosis prevention, care and control: key operational challenges and research priorities. BMC infectious diseases, 2016. 16(1): p. 1-12.

54. Saqib, S.E., M.M. Ahmad, and C. Amezcua-Prieto, Economic burden of tuberculosis and its coping mechanism at the household level in Pakistan. The Social Science Journal, 2018. 55(3): p. 313-322.

55. Fuady, A., et al., Effect of financial support on reducing the incidence of catastrophic costs among tuberculosis-affected households in Indonesia: eight simulated scenarios. Infectious diseases of poverty, 2019. 8(1): p. 1-14.

56. Wingfield, T., et al., The economic effects of supporting tuberculosis-affected households in Peru. European Respiratory Journal, 2016. 48(5): p. 13961410.

57. Fuady, A., et al., Effect of financial support on reducing the incidence of catastrophic costs among tuberculosis-affected households in Indonesia: eight simulated scenarios. Infectious diseases of poverty, 2019. 8(1): p. 10. 
58. Sinanovic, E., et al., Cost and cost-effectiveness of community-based care for tuberculosis in Cape Town, South Africa. The international journal of tuberculosis and lung disease, 2003. 7(9): p. S56-S62.

59. Datiko, D.G. and B. Lindtjørn, Cost and cost-effectiveness of smear-positive tuberculosis treatment by Health Extension Workers in Southern Ethiopia: a community randomized trial. PLoS One, 2010. 5(2).

60. Organization, W.H. and W.E.C.o. Malaria, WHO Expert Committee on Malaria: twentieth report. 2000: World Health Organization.

61. Xiang, L., et al., The impact of the new cooperative medical scheme on financial burden of tuberculosis patients: evidence from six counties in China. Infectious diseases of poverty, 2016. 5(1): p. 8.

62. Zhou, C., et al., The effect of NCMS on catastrophic health expenditure and impoverishment from tuberculosis care in China. International journal for equity in health, 2016. 15(1): p. 172.

63. World Health Organization, Designing health financing systems to reduce catastrophic health expenditure. 2005, World Health Organization.

64. World Health Organization, Protocol for survey to determine direct and indirect costs due to TB and to estimate proportion of TB-affected households experiencing catastrophic total costs due to TB. Geneva: World Health Organization, 2015.

\section{Tables}


Table 1

Studies that addressed catastrophic cost included in systematic review analysis

\begin{tabular}{|c|c|c|c|c|c|c|c|c|}
\hline $\begin{array}{l}\text { Author, Year, } \\
\text { country }\end{array}$ & Study design & $\begin{array}{l}\text { Population } \\
\text { Criteria + } \\
\text { inclusion } \\
\text { and } \\
\text { exclusion }\end{array}$ & $\begin{array}{l}\text { Sample } \\
\text { size/Sex/Age }\end{array}$ & $\begin{array}{l}\text { Tool used in } \\
\text { cost } \\
\text { estimation }\end{array}$ & $\begin{array}{l}\text { Studied } \\
\text { outcome }\end{array}$ & $\begin{array}{l}\text { CTC (COP) } \\
\text { Predictors of } \\
\text { CTC }\end{array}$ & $\begin{array}{l}\text { CHE and its } \\
\text { predictors }\end{array}$ & $\begin{array}{l}\text { Notes } \\
\text { Coping } \\
\text { cost }\end{array}$ \\
\hline \multirow{3}{*}{$\begin{array}{l}\text { Shewade } \\
2018 \\
\text { India(Axshya) } \\
{[17]}\end{array}$} & \multirow[t]{3}{*}{$\begin{array}{l}\text { Community based } \\
\text { cohort study }\end{array}$} & $\begin{array}{l}\text { Sputum + ve } \\
\text { pulmonary } \\
\text { TB }\end{array}$ & $\begin{array}{l}\text { Sample size } \\
=465\end{array}$ & \multirow[t]{3}{*}{$\begin{array}{l}\text { Structured } \\
\text { questionnaire }\end{array}$} & \multirow[t]{3}{*}{ CTC } & $\begin{array}{l}\text { ACF } 10.3 \% \& P C F \\
11.5 \% \text { at }(20 \%)\end{array}$ & \multirow[t]{3}{*}{ 一 } & \multirow[t]{3}{*}{-} \\
\hline & & ACF\&PCF & $\begin{array}{l}\text { Sex: Male = } \\
66 \%\end{array}$ & & & $\begin{array}{l}\text { Predictors: not } \\
\text { mentioned }\end{array}$ & & \\
\hline & & $\begin{array}{l}3 / 2016- \\
2 / 2017\end{array}$ & $\begin{array}{l}\text { Age (years): } \\
42 \pm 17\end{array}$ & & & & & \\
\hline \multirow{4}{*}{$\begin{array}{l}\text { Muniyandi, } \\
\text { 2020, India } \\
\text { [31] }\end{array}$} & \multirow{4}{*}{$\begin{array}{l}\text { Community based } \\
\text { /Cross-sectional }\end{array}$} & TB patients & \multirow{4}{*}{$\begin{array}{l}\text { Sample size } \\
=384 \text { sex: } \\
\text { Male= }(67 \%)\end{array}$} & \multirow{4}{*}{$\begin{array}{l}\text { WHO TB cost } \\
\text { surveys }\end{array}$} & \multirow{4}{*}{$\begin{array}{l}\text { CTC + it's } \\
\text { predictors }\end{array}$} & $31 \%$ at $(20 \%)$ & \multirow[t]{4}{*}{-} & \multirow[t]{4}{*}{ 一 } \\
\hline & & PTB/EPTB & & & & Predictors: & & \\
\hline & & & & & & $\begin{array}{l}\text { socioeconomic } \\
\text { seaments }\end{array}$ & & \\
\hline & & $\begin{array}{l}2 / 2017 \\
-3 / 2018\end{array}$ & & & & & & \\
\hline \multirow{4}{*}{$\begin{array}{l}\text { Wingfield, } \\
\text { 2016,, Peru } \\
\text { [26] }\end{array}$} & \multirow{4}{*}{$\begin{array}{l}\text { Community based } \\
\text { /Prospective cohort }\end{array}$} & $\begin{array}{l}\text { Any patient } \\
\text { treated with }\end{array}$ & \multirow{4}{*}{$\begin{array}{l}\text { Sample size } \\
=876 \\
\text { Sex: male = } \\
59 \% \\
\begin{array}{l}\text { Age } \geq 15 \\
\text { years }\end{array}\end{array}$} & \multirow[t]{4}{*}{ Questionnaire } & \multirow{4}{*}{$\begin{array}{l}\text { CTC }+ \text { it`s } \\
\text { predictors }\end{array}$} & $39 \%$ at $(20 \%)$ & \multirow[t]{4}{*}{-} & \multirow[t]{4}{*}{-} \\
\hline & & $\begin{array}{l}\text { the Peruvian } \\
\text { national TB } \\
\text { control } \\
\text { programme }\end{array}$ & & & & $\begin{array}{l}\text { Predictors: } \\
\text { Inadequate } \\
\text { nutrition, severe } \\
\text { TB, hidden }\end{array}$ & & \\
\hline & & $\begin{array}{l}\text { DS \& MDR } \\
(11 \%)\end{array}$ & & & & costs/adherence & & \\
\hline & & $\begin{array}{l}2 / 2014- \\
8 / 2014\end{array}$ & & & & & & \\
\hline \multirow{3}{*}{$\begin{array}{l}\text { Muniyandi, } \\
\text { 2019, India } \\
\text { [18] }\end{array}$} & \multirow[t]{3}{*}{$\begin{array}{l}\text { Community based/ } \\
\text { Cross-sectional }\end{array}$} & $\begin{array}{l}\text { TB PT } \geq 15 \\
y \text { of age }\end{array}$ & $\begin{array}{l}\text { Sample size } \\
=336\end{array}$ & \multirow{3}{*}{$\begin{array}{l}\text { pre-coded } \\
\text { interview } \\
\text { schedule }\end{array}$} & СTC & $\begin{array}{l}\text { PCF (29\%), ACF } \\
(9 \%) \text {, at (20\%) }\end{array}$ & - & - \\
\hline & & ACF vs PCF & $\begin{array}{l}\text { Sex: Male = } \\
(77 \%)\end{array}$ & & & $\begin{array}{l}\text { Predictors: not } \\
\text { mentioned }\end{array}$ & & \\
\hline & & $\begin{array}{l}\text { 10/2016- } \\
3 / 2018\end{array}$ & All age & & & & & \\
\hline $\begin{array}{l}\text { Fuady, 2020, } \\
\text { Indonesia } \\
\text { [12] }\end{array}$ & $\begin{array}{l}\text { Hospital-based/ } \\
\text { Cohort }\end{array}$ & $\begin{array}{l}\mathrm{Pt} \geq 18 \text { yrs, } \\
\text { treatment } \geq \\
1 \text { Month or }\end{array}$ & $\begin{array}{l}\text { Sample size } \\
=252\end{array}$ & $\begin{array}{l}\text { Tool adapted } \\
\text { to the } \\
\text { Indonesian }\end{array}$ & $\begin{array}{l}\text { CTC+ it`s } \\
\text { predictors }\end{array}$ & $\begin{array}{l}46 \%, 38 \%, 33 \%, \\
26 \%, 22 \%, 17 \%, \\
\text { at }(10 \%)(15 \%)\end{array}$ & - & 一 \\
\hline & & $\begin{array}{l}\text { completed } \\
\text { treatment } \\
\text { since }<1\end{array}$ & $\begin{array}{l}\text { Sex: Male = } \\
(54 \%)\end{array}$ & context & & $\begin{array}{l}(20 \%)(25 \%) \\
(30 \%) \\
(35 \%)\end{array}$ & & \\
\hline & & & $\begin{array}{l}A g e \geq 18 \\
\text { years }\end{array}$ & & & $\begin{array}{l}\text { Predictors: } \\
\text { Prolonged }\end{array}$ & & \\
\hline & & & & & & $\begin{array}{l}\text { treatment, } \\
\text { additional visits }\end{array}$ & & \\
\hline & & $7-9 / 2016$ & & & & $\begin{array}{l}\text { needed to } \\
\text { complete the full } \\
\text { treatment course }\end{array}$ & & \\
\hline $\begin{array}{l}\text { Mullerpattan, } \\
2018 \text {, India }\end{array}$ & $\begin{array}{l}\text { Hospital } \\
\text { based/Cross- }\end{array}$ & $\begin{array}{l}\text { Drug } \\
\text { resistant-TB, }\end{array}$ & $\begin{array}{l}\text { Sample size } \\
=50\end{array}$ & $\begin{array}{l}\text { Not } \\
\text { mentioned }\end{array}$ & СТC & $\begin{array}{l}68 \% 78 \% \text {, at } \\
(20 \%),(10 \%)\end{array}$ & - & - \\
\hline & & & $\begin{array}{l}\text { Sex: Male = } \\
30 \%\end{array}$ & & & $\begin{array}{l}\text { Predictors: not } \\
\text { mentioned }\end{array}$ & & \\
\hline & & $\begin{array}{l}\text { MDR, } \\
\text { private } \\
\text { sector }\end{array}$ & $\begin{array}{l}\text { Mean age }= \\
30 \text { yrs }\end{array}$ & & & & & \\
\hline & & $\begin{array}{l}8 / 2015- \\
2 / 2016\end{array}$ & & & & & & \\
\hline $\begin{array}{l}\text { Lu, 2020, } \\
\text { China [42] }\end{array}$ & $\begin{array}{l}\text { Community + } \\
\text { Hospital }\end{array}$ & $\begin{array}{l}\text { Culture- } \\
\text { confirmed }\end{array}$ & $\begin{array}{l}\text { Sample size } \\
=248\end{array}$ & $\begin{array}{l}\text { Standardized } \\
\text { questionnaire }\end{array}$ & СТC & $22.2 \%$, at $(20 \%)$ & - & - \\
\hline & $\begin{array}{l}\text { based/Cross- } \\
\text { sectional }\end{array}$ & $\begin{array}{l}\text { pulmonary } \\
\text { TB }\end{array}$ & $\begin{array}{l}\text { sex: Male } \\
(54.9 \%)\end{array}$ & & & $\begin{array}{l}\text { Predictors: not } \\
\text { mentioned }\end{array}$ & & \\
\hline & & $\begin{array}{l}12 / 2014- \\
12 / 2015\end{array}$ & $\begin{array}{l}\text { Mean Age = } \\
34(26-49)\end{array}$ & & & & & \\
\hline
\end{tabular}




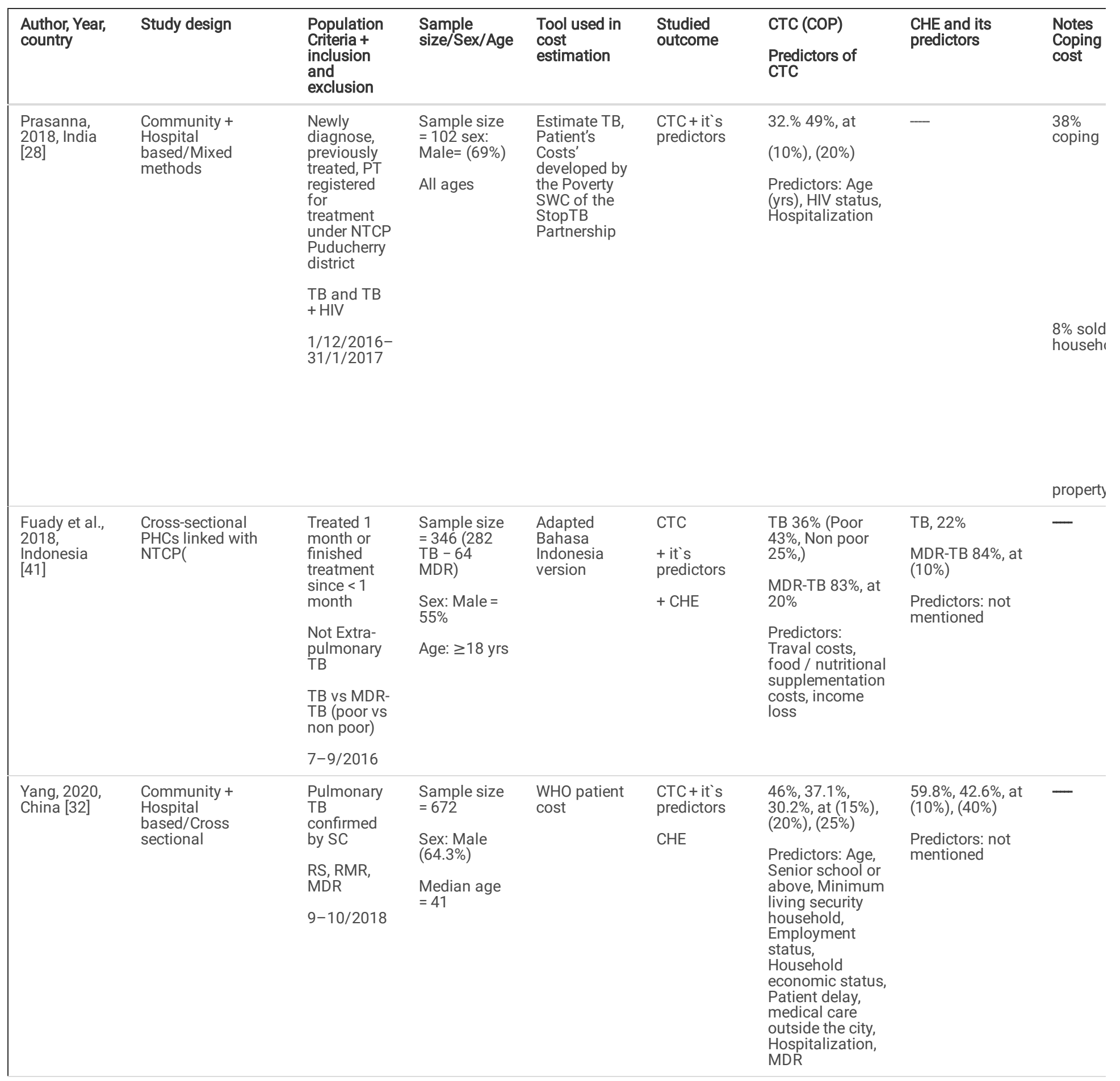

ACF: Active Case Finding; PCF: Passive Case Finding; SP: Smear Positive; TB: Tuberculosis; CTC: Catastrophic total cost; COP: Cut-off point; CHE: Catastroph Expenditure; DS: Drug Sensitive; HB: Hospital Based, HCB: Health care centers Based; LOS: Length of Stay; MDR: Multi Drug Resistant; NTCP: National TB CoI PHCB: Public Health Centers Based; RMR: Rifampicin-nonresistant; RS Rifampicin-susceptible; SC: Sputum Culture; SWC: Sub-Working Group; TBMU: Tubercl 


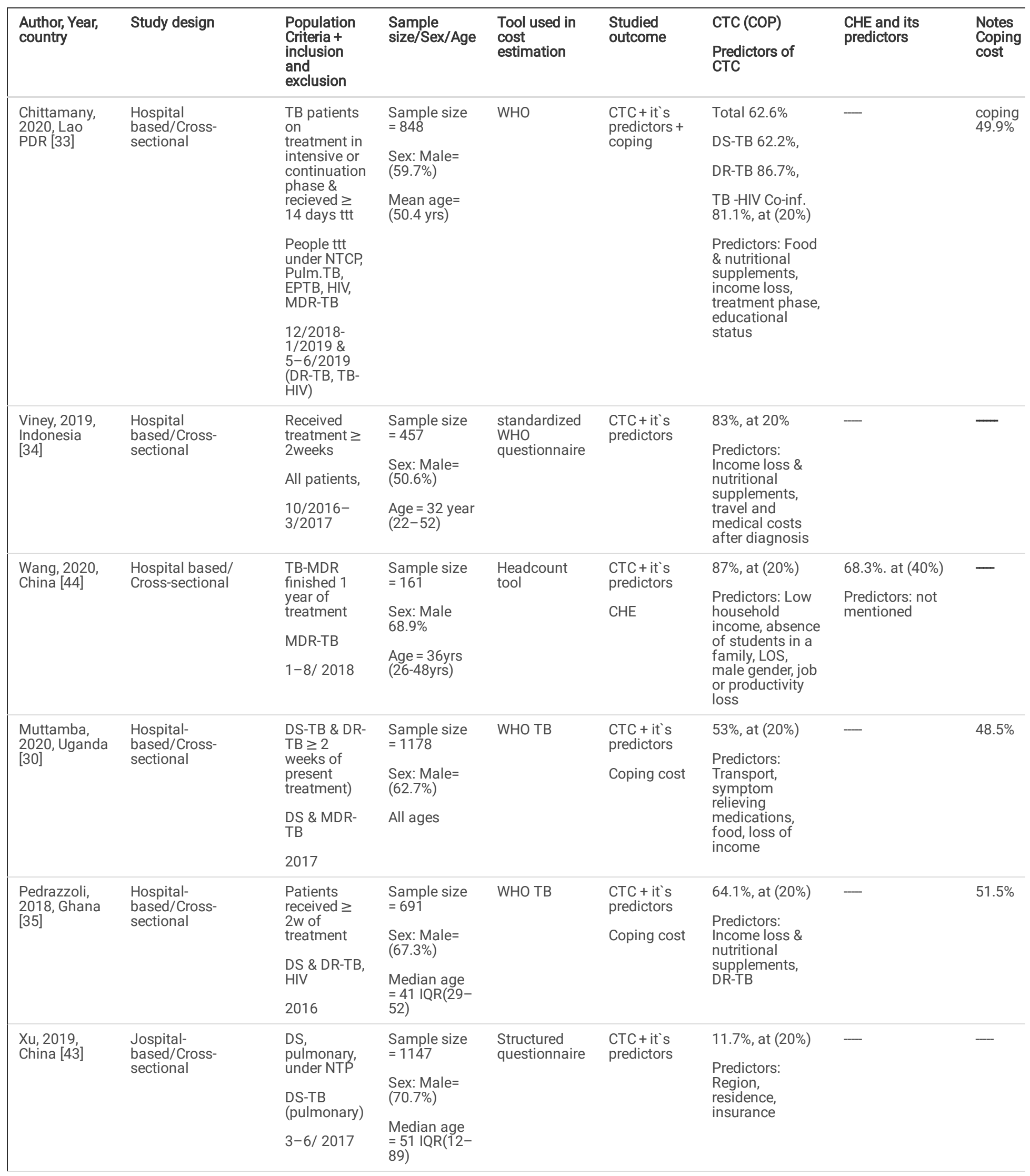

ACF: Active Case Finding; PCF: Passive Case Finding; SP: Smear Positive; TB: Tuberculosis; CTC: Catastrophic total cost; COP: Cut-off point; CHE: Catastroph Expenditure; DS: Drug Sensitive; HB: Hospital Based, HCB: Health care centers Based; LOS: Length of Stay; MDR: Multi Drug Resistant; NTCP: National TB CoI PHCB: Public Health Centers Based; RMR: Rifampicin-nonresistant; RS Rifampicin-susceptible; SC: Sputum Culture; SWC: Sub-Working Group; TBMU: Tuberci 


\begin{tabular}{|c|c|c|c|c|c|c|c|c|}
\hline $\begin{array}{l}\text { Author, Year, } \\
\text { country }\end{array}$ & Study design & $\begin{array}{l}\text { Population } \\
\text { Criteria + } \\
\text { inclusion } \\
\text { and } \\
\text { exclusion }\end{array}$ & $\begin{array}{l}\text { Sample } \\
\text { size/Sex/Age }\end{array}$ & $\begin{array}{l}\text { Tool used in } \\
\text { cost } \\
\text { estimation }\end{array}$ & $\begin{array}{l}\text { Studied } \\
\text { outcome }\end{array}$ & $\begin{array}{l}\text { CTC (COP) } \\
\text { Predictors of } \\
\text { CTC }\end{array}$ & $\begin{array}{l}\text { CHE and its } \\
\text { predictors }\end{array}$ & $\begin{array}{l}\text { Notes } \\
\text { Coping } \\
\text { cost }\end{array}$ \\
\hline $\begin{array}{l}\text { Ikram, 2020, } \\
\text { Pakistan [36] }\end{array}$ & $\begin{array}{l}\text { Hospital- } \\
\text { based/Cross- } \\
\text { sectional }\end{array}$ & $\begin{array}{l}\text { diagnosis } \\
\text { since > } 3 \\
\text { mons } \\
\text { Pulmonary } \\
\text { \& DS, Not } \\
\text { AIDS, } \\
\text { Hepatitis, or } \\
\text { DM } \\
\text { TB-patients } \\
\text { Not } \\
\text { mentioned }\end{array}$ & $\begin{array}{l}\text { Sample size } \\
=400 \\
\text { Sex: Male= } \\
(47 \%) \\
\text { Median age } \\
=30(22-49 \\
.50)\end{array}$ & $\begin{array}{l}\text { WHO generic } \\
\text { instrument }\end{array}$ & $\begin{array}{l}\text { CTC + it`s } \\
\text { predictors }\end{array}$ & $\begin{array}{l}67 \% \text {, at (20\%) } \\
\text { Predictors: } \\
\text { Availability of } \\
\text { paid sick leave, } \\
\text { number of } \\
\text { follow up visits, } \\
\text { Job loss }\end{array}$ & - & - \\
\hline $\begin{array}{l}\text { Nhung, 2018, } \\
\text { Viet Nam [37] }\end{array}$ & $\begin{array}{l}\text { Community-based/ } \\
\text { Cross-sectional } \\
\text { study }\end{array}$ & $\begin{array}{l}\text { (DS-TB \& } \\
\text { MDR-TB) } \\
\text { including } \\
\text { children on } \\
\text { ttt > } 14 \text { days } \\
\text { All ages DS } \\
\& \text { MDR-TB } \\
7-10 / 2016\end{array}$ & $\begin{array}{l}\text { Sample size } \\
=735 \\
\text { Sex: Male= } \\
(75.9 \%) \\
\text { Median age } \\
=47(\mathrm{IQR} \\
35-58)\end{array}$ & $\begin{array}{l}\text { WHO generic } \\
\text { instrument }\end{array}$ & $\begin{array}{l}\text { CTC + } \\
\text { It`s } \\
\text { predictors } \\
\text { Coping } \\
\text { (Dissaving } \\
\text { mechanism) }\end{array}$ & $\begin{array}{l}\text { Total } 63 \%, 48 \% \text {, } \\
35 \% \\
\text { MDR } 98 \%, 98 \% \text {, } \\
39 \% \text {, } \\
\text { DS } 59.6 \%, 43 \% \\
30 \%, \text { at }(20 \%) \text {, } \\
(30 \%),(40 \%) \\
\text { Predictors: } \\
\text { Purchase special } \\
\text { foods, travel, } \\
\text { nutritional } \\
\text { supplements, } \\
\text { and } \\
\text { accommodation }\end{array}$ & $\begin{array}{l}\text { Total } 15 \% 7.9 \% \\
2.8 \% \\
\text { MDR } 77 \% 56.2 \% \\
21.3 \% \\
\text { DS } 9.5 \% 3.7 \% \\
1.2 \% \text {, at } \\
\left(\begin{array}{l}10 \%)(20 \%) \\
(40 \%)\end{array}\right.\end{array}$ & $\begin{array}{l}25 \% \text { loa } \\
16 \% \text { ust } \\
\text { of savir } \\
5.8 \% \text { sa } \\
\text { of asse } \\
-22 \% \\
\text { food } \\
\text { insecuri } \\
0.7 \% \text { los } \\
\text { of job } \\
1.6 \% \text { ch } \\
\text { interrup } \\
\text { schoolir }\end{array}$ \\
\hline $\begin{array}{l}\text { McAllister, } \\
\text { etal., 2020, } \\
\text { Indonesia } \\
\text { [38] }\end{array}$ & $\begin{array}{l}\text { Hospital- } \\
\text { based/Cross- } \\
\text { sectional }\end{array}$ & $\begin{array}{l}\text { Newly } \\
\text { diagnosed } \\
\text { pulmonary } \\
\text { TB. } \\
\text { Private/ } \\
\text { non-private } \\
\text { sector } \\
10 / 2017- \\
1 / 2019\end{array}$ & $\begin{array}{l}\text { Sample size } \\
=469 \\
\text { Sex: Male } \\
(49.25 \%) \\
\text { Age: } \geq 18 \text { yrs }\end{array}$ & WHO & CTC & $\begin{array}{l}38.6 \% \\
26.5 \% 21.7 \% \text {, at } \\
(10 \%)(20 \%) \\
(25 \%) \\
\text { Predictors: not } \\
\text { mentioned }\end{array}$ & - & - \\
\hline $\begin{array}{l}\text { Tomeny, } \\
\text { 2020, Cavite } \\
\text { [15] }\end{array}$ & $\begin{array}{l}\text { Hospital = } \\
\text { based/Cross- } \\
\text { sectional }\end{array}$ & $\begin{array}{l}\text { Patients } \geq \\
16 \text { yrs on } \\
\text { treatment of } \\
\text { pulmonary } \\
\text { TB } \\
\text { DS-TB vs } \\
\text { MDR-TB } \\
5-8 / 2016\end{array}$ & $\begin{array}{l}\text { Sample size } \\
=194 \\
\text { Sex: Male } \\
(66 \%) \\
\text { Age: } \geq 16 \text { yrs }\end{array}$ & WHO & $\begin{array}{l}\text { CTC+ it`s } \\
\text { predictors }\end{array}$ & $\begin{array}{l}\text { DS-TB 28\% } \\
\text { MDR-TB 80\%, at } \\
(20 \%) \text {, } \\
\text { Predictors: } \\
\text { Travel, } \\
\text { accommodation, } \\
\text { nutritional } \\
\text { supplement, } \\
\text { food }\end{array}$ & - & - \\
\hline
\end{tabular}

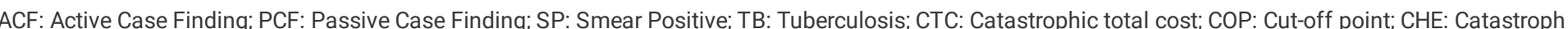

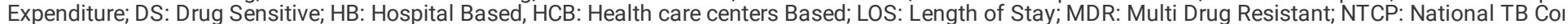

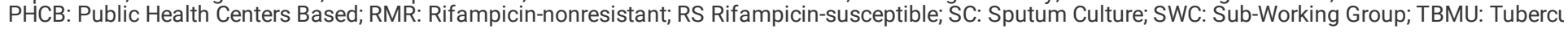




\begin{tabular}{|c|c|c|c|c|c|c|c|c|}
\hline $\begin{array}{l}\text { Author, Year, } \\
\text { country }\end{array}$ & Study design & $\begin{array}{l}\text { Population } \\
\text { Criteria + } \\
\text { inclusion } \\
\text { and } \\
\text { exclusion }\end{array}$ & $\begin{array}{l}\text { Sample } \\
\text { size/Sex/Age }\end{array}$ & $\begin{array}{l}\text { Tool used in } \\
\text { cost } \\
\text { estimation }\end{array}$ & $\begin{array}{l}\text { Studied } \\
\text { outcome }\end{array}$ & $\begin{array}{l}\text { CTC (COP) } \\
\text { Predictors of } \\
\text { CTC }\end{array}$ & $\begin{array}{l}\text { CHE and its } \\
\text { predictors }\end{array}$ & $\begin{array}{l}\text { Notes } \\
\text { Coping } \\
\text { cost }\end{array}$ \\
\hline $\begin{array}{l}\text { Stracker, } \\
2019, \text { South } \\
\text { Africa [5] }\end{array}$ & $\begin{array}{l}\text { Hospital- } \\
\text { based/Cross- } \\
\text { sectional }\end{array}$ & $\begin{array}{l}2 \text { months } \\
\text { after } \\
\text { diagnosis, > } \\
18 \text { yrs, } \\
\text { transferred } \\
\text { patients } \\
\text { Adults } \\
10 / 2017- \\
1 / 2018\end{array}$ & $\begin{array}{l}\text { Sample size } \\
=237 \\
\text { Sex: Male } \\
(54 \%) \\
\text { Age: } \geq 18 \text { yrs }\end{array}$ & WHO tool & $\begin{array}{l}\text { CTC+ it`s } \\
\text { predictors }\end{array}$ & $\begin{array}{l}28 \% \text {, at }(20 \%) \\
\text { Predictors: } \\
\text { Transport, } \\
\text { treatment, } \\
\text { income loss, } \\
\text { time lost care- } \\
\text { seeking }\end{array}$ & - & - \\
\hline $\begin{array}{l}\text { Y.Z Ruan, } \\
\text { 2016, China } \\
{[14]}\end{array}$ & $\begin{array}{l}\text { Hospital- } \\
\text { based/Cross- } \\
\text { sectional }\end{array}$ & $\begin{array}{l}\text { MDR-TB } \\
6-8 / 2012\end{array}$ & $\begin{array}{l}\text { Sample size } \\
=73 \\
\text { Sex: Male= } \\
(48 \%) \\
\text { All ages }\end{array}$ & $\begin{array}{l}\text { Lumley T. } \\
\text { Survey }\end{array}$ & $\begin{array}{l}\text { CTC + it`s } \\
\text { predictors } \\
\text { CHE + it's } \\
\text { predictors } \\
\text { Hardship } \\
\text { financing }\end{array}$ & $\begin{array}{l}78 \% \text {, at }(20 \%) \\
\text { Predictors: } \\
\text { Treatment, tests, } \\
\text { nutrition, } \\
\text { transportation, } \\
\text { and } \\
\text { accommodation. } \\
\text { time loss }\end{array}$ & $\begin{array}{l}74 \% \text {, at }(40 \%) \\
\text { Predictors: } \\
\text { Treatment, } \\
\text { nutrition, } \\
\text { transportation } \\
\text { and } \\
\text { accommodation. }\end{array}$ & $(62 \%)$ \\
\hline $\begin{array}{l}\text { Don } \\
\text { Mudzengi, } \\
\text { 2017, South } \\
\text { Africa [16] }\end{array}$ & $\begin{array}{l}\text { Hospital- } \\
\text { based/Cross- } \\
\text { sectional }\end{array}$ & $\begin{array}{l}\text { Diagnosis } \\
3-5 \text { month } \\
\text { prior to the } \\
\text { interview } \\
\text { TB, HIV, or } \\
\text { Both } \\
4-10 / 2013\end{array}$ & $\begin{array}{l}\text { Sample size } \\
=454 \\
\text { Sex: Male } \\
(36 \%) \\
\text { Age: } \geq 18 \\
\text { years }\end{array}$ & $\begin{array}{l}\text { TB Coaliation } \\
\text { tool }\end{array}$ & $\begin{array}{l}\text { CTC } \\
\text { coping \% }\end{array}$ & $\begin{array}{l}\text { Total } 60 \%(10 \%) \\
\text { TB/HIV } \\
79 \% 67 \% 65 \% \\
64 \% 61 \% \\
\text { TB only: } 55 \% \\
53 \% 47 \% 47 \% \\
45 \% \\
\text { HIV only: } 72 \% \\
60 \% 55 \% 52 \% \\
49 \% \text {, at }(5 \%), \\
(10 \%), \\
(15 \%),(20 \%), \\
(25 \%)\end{array}$ & - & $\begin{array}{l}15 \% \text { HII } \\
\text { only, } \\
6 \% \\
\text { TB/HIV, } \\
8 \% \text { TB } \\
\text { only }\end{array}$ \\
\hline $\begin{array}{l}\text { Suman } \\
\text { Gurung, 2019, } \\
\text { Nepal [39] }\end{array}$ & $\begin{array}{l}\text { Hospital- } \\
\text { based/Cross- } \\
\text { sectional }\end{array}$ & $\begin{array}{l}\text { Adults } \geq 18 \\
\text { yrs, new and } \\
\text { relapse TB } \\
\text { cases, } \\
\text { residents of } \\
\text { Nepal } \\
\text { New and } \\
\text { relapse TB } \\
\text { (ACF vs } \\
\text { PCF) } \\
4-10 / 2013\end{array}$ & $\begin{array}{l}\text { Sample size } \\
=99 \\
\text { Sex: Male= } \\
(71 \%) \\
\text { Age: } \geq 15 \\
\text { years }\end{array}$ & $\begin{array}{l}\text { WHO TB } \\
\text { patient } \\
\text { costing tool }\end{array}$ & $\begin{array}{l}\text { CTC+ it`s } \\
\text { predictors }\end{array}$ & $\begin{array}{l}\text { Total 52\% } \\
\text { PCF 61\% } \\
\text { ACF 44\%, at } \\
(20 \%) \\
\text { Predictors: } \\
\text { Gender, Age, } \\
\text { Disease (new, } \\
\text { category (newe } \\
\text { relapse), Poverty } \\
\text { line, Dissaving, } \\
\text { Financial and } \\
\text { social impact }\end{array}$ & - & - \\
\hline $\begin{array}{l}\text { Rebecca L. } \\
\text { Walctt 2020, } \\
\text { Uganda [13] }\end{array}$ & $\begin{array}{l}\text { Hospital- } \\
\text { based/Retrospective } \\
\text { cohort }\end{array}$ & 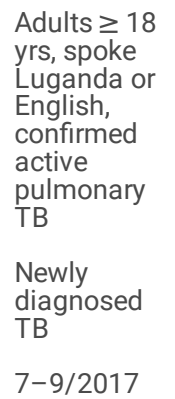 & $\begin{array}{l}\text { Sample size } \\
=224 \\
\text { Sex: Male= } \\
(60.2 \%) \\
\text { age: } \geq 18 \\
\text { years }\end{array}$ & $\begin{array}{l}\text { Adapted } \\
\text { version of } \\
\text { Tool to } \\
\text { Estimate } \\
\text { Patients' Cost } \\
\text { (stop TB } \\
\text { partnership) }\end{array}$ & $\begin{array}{l}\text { CTC+it`s } \\
\text { predictors }\end{array}$ & $\begin{array}{l}\text { 41.8\%, at (20\%) } \\
\text { Predictors: } \\
\text { Hospitalization, } \\
\text { experience of } \\
\text { coping costs, } \\
\text { low income } \\
\text { status, age, } \\
\text { education, HIV + } \\
\text { quit job, female } \\
\text { gender }\end{array}$ & - & - \\
\hline
\end{tabular}

ACF: Active Case Finding; PCF: Passive Case Finding; SP: Smear Positive; TB: Tuberculosis; CTC: Catastrophic total cost; COP: Cut-off point; CHE: Catastroph Expenditure; DS: Drug Sensitive; HB: Hospital Based, HCB: Health care centers Based; LOS: Length of Stay; MDR: Multi Drug Resistant; NTCP: National TB CoI PHCB: Public Health Centers Based; RMR: Rifampicin-nonresistant; RS Rifampicin-susceptible; SC: Sputum Culture; SWC: Sub-Working Group; TBMU: Tubercı 


\begin{tabular}{|c|c|c|c|c|c|c|c|c|}
\hline $\begin{array}{l}\text { Author, Year, } \\
\text { country }\end{array}$ & Study design & $\begin{array}{l}\text { Population } \\
\text { Criteria + } \\
\text { inclusion } \\
\text { and } \\
\text { exclusion }\end{array}$ & $\begin{array}{l}\text { Sample } \\
\text { size/Sex/Age }\end{array}$ & $\begin{array}{l}\text { Tool used in } \\
\text { cost } \\
\text { estimation }\end{array}$ & $\begin{array}{l}\text { Studied } \\
\text { outcome }\end{array}$ & $\begin{array}{l}\text { CTC (COP) } \\
\text { Predictors of } \\
\text { CTC }\end{array}$ & $\begin{array}{l}\text { CHE and its } \\
\text { predictors }\end{array}$ & $\begin{array}{l}\text { Notes } \\
\text { Coping } \\
\text { cost }\end{array}$ \\
\hline $\begin{array}{l}\text { Mihir P. Rpan, } \\
\text { 2020, India } \\
\text { [46] }\end{array}$ & Cross-sectional & $\begin{array}{l}\text { Patients } \geq \\
18 \text { yrs on } \\
\text { treatment, } \\
\text { registered } \\
\text { under public } \\
\text { sector } \\
\\
\text { Not } \\
\text { previously } \\
\text { 1/2019 } \\
\text { treated. } \\
\text { DS } \\
\text { pulmonary } \\
\text { TB } \\
\text { (n) }\end{array}$ & $\begin{array}{l}\text { Sample size } \\
=458 \\
\text { Sex: Male= } \\
(70 \%) \\
\text { Median age } \\
\text { IQR: } 35 \text { (23- } \\
\text { 50), }\end{array}$ & $\begin{array}{l}\text { Adapted } \\
\text { WHO costing } \\
\text { tool }\end{array}$ & $\begin{array}{l}\text { \% CTC } \\
\text { Coping }\end{array}$ & $\begin{array}{l}14 \% 7 \% 5 \% 4 \% \text {, } \\
\text { at (5\%) } \\
(10 \%) \\
(15 \%) \\
\\
\text { (20\%) } \\
\text { Predictors: not } \\
\text { mentioned }\end{array}$ & - & $18 \%$ \\
\hline $\begin{array}{l}\text { Collins } \\
\text { Timire, 2020, } \\
\text { Zimbabwe } \\
{[40]}\end{array}$ & $\begin{array}{l}\text { Hospital- } \\
\text { based/Cross- } \\
\text { sectional survey }\end{array}$ & $\begin{array}{l}\text { All ages on } \\
\text { treatment } \\
\text { for DS/ } \\
\text { MDR } \\
\text { DS, MDR } \\
23 / 7-31 /-8 \\
2018\end{array}$ & $\begin{array}{l}\text { Sample size } \\
=900 \\
\text { Sex: Male } \\
(56 \%) \\
\text { Mean age: } \\
36.9 \pm 14.7\end{array}$ & $\begin{array}{l}\text { Adapted } \\
\text { WHO costing } \\
\text { tool }\end{array}$ & $\begin{array}{l}\text { CTC + it's } \\
\text { predictors }\end{array}$ & $\begin{array}{l}\text { 80\%, at (20\%) } \\
\text { Predictors: } \\
\text { Gender, Age, TB } \\
\text { type, } \\
\text { treatment phase, } \\
\text { treatment delay } \\
\text { HIV status, } \\
\text { Breadwinner, } \\
\text { Income quintile, } \\
\text { Location of } \\
\text { health facility }\end{array}$ & - & - \\
\hline $\begin{array}{l}\text { Gadallah } \\
\text { 2018 Egypt } \\
\text { [27] }\end{array}$ & $\begin{array}{l}\text { Hospital- } \\
\text { based.Prospective } \\
\text { cohort }\end{array}$ & $\begin{array}{l}\text { New } \\
\text { patients } \\
\text { attending } \\
\text { TBMUs for } \\
\text { starting their } \\
\text { treatment, } \\
\text { have } \\
\text { consent } \\
\text { TB patients } \\
1-6 / 2019\end{array}$ & $\begin{array}{l}\text { Sample size } \\
=257 \\
\text { Sex: Male } \\
(61.9 \%) \\
\text { Mean age: } \\
38.3 \pm 14.8\end{array}$ & $\begin{array}{l}\text { Tool to } \\
\text { estimate TB } \\
\text { patient cost } \\
\text { from gp stop } \\
\text { TB } \\
\text { partnership }\end{array}$ & $\begin{array}{l}\text { CTC + it`s } \\
\text { predictors } \\
\text { Coping \% }\end{array}$ & $\begin{array}{l}22.6 \% 24.1 \% \\
6.6 \% \text {, at }(10 \%) \\
(20 \%),(30 \%) \\
\text { Predictors: } \\
\text { Age, Gender } \\
\text { Employment } \\
\text { Crowding index } \\
\text { Governorates } \\
\text { Income } \\
\text { Coping }\end{array}$ & - & $11.3 \%$ \\
\hline
\end{tabular}

ACF: Active Case Finding; PCF: Passive Case Finding; SP: Smear Positive; TB: Tuberculosis; CTC: Catastrophic total cost; COP: Cut-off point; CHE: Catastroph Expenditure; DS: Drug Sensitive; HB: Hospital Based, HCB: Health care centers Based; LOS: Length of Stay; MDR: Multi Drug Resistant; NTCP: National TB Col PHCB: Public Health Centers Based; RMR: Rifampicin-nonresistant; RS Rifampicin-susceptible; SC: Sputum Culture; SWC: Sub-Working Group; TBMU: Tubercl 
Table 2

Pooled proportion of catastrophic cost at $20 \%$ among drug sensitive, drug resistant, TB-HIV, active \& passive case finding patients, direct cost to total cost, and catastrophic health expenditure.

\begin{tabular}{|c|c|c|c|c|c|}
\hline \multicolumn{6}{|c|}{ 1. Pooled proportion of catastrophic cost at $20 \%$ among drug sensitive } \\
\hline Study & Event & Total & Proportion & $95 \% \mathrm{Cl}$ & Weight \\
\hline Fuady,2020 & 83 & 252 & 0.33 & {$[0.27-0.39]$} & $9.30 \%$ \\
\hline Wingfield, 2014 & 295 & 783 & 0.38 & {$[0.34-0.41]$} & $12.20 \%$ \\
\hline McAllister., 2020 & 22 & 83 & 0.27 & {$[0.17-0.37]$} & $5.10 \%$ \\
\hline Gadallah, 2018 & 62 & 257 & 0.24 & {$[0.19-0.30]$} & $8.80 \%$ \\
\hline Muniyandi, 2020 & 141 & 455 & 0.31 & {$[0.27-0.35$} & $10.90 \%$ \\
\hline Prasanna, 2018 & 33 & 102 & 0.32 & {$[0.23-0.42]$} & $6.20 \%$ \\
\hline Fuady, 2018 & 101 & 282 & 0.36 & {$[0.30-0.42]$} & $9.80 \%$ \\
\hline Yang, 2020 & 197 & 586 & 0.34 & {$[0.30-0.38]$} & $11.50 \%$ \\
\hline Tomeny, 2020 & 47 & 169 & 0.28 & {$[0.21-0.35]$} & $7.70 \%$ \\
\hline Stracker, 2019 & 90 & 327 & 0.28 & {$[0.23-0.33]$} & $9.80 \%$ \\
\hline Rebecca L. Walctt, 2020 & 82 & 196 & 0.42 & {$[0.35-0.49]$} & $8.80 \%$ \\
\hline Random effect model & 1153 & 3492 & 0.32 & {$[0.29-0.35]$} & \\
\hline \multicolumn{6}{|l|}{ Heterogeneity $\left.\right|^{2}=70 \%$} \\
\hline \multicolumn{6}{|c|}{ 2. Pooled proportion of catastrophic cost at $20 \%$ among drug resistant } \\
\hline Mullerpattan, 2018 & 34 & 50 & 0.68 & {$[0.53-0.80]$} & $12.50 \%$ \\
\hline Fuady, 2018 & 53 & 64 & 0.83 & {$[0.71-0.91]$} & $11.60 \%$ \\
\hline Yang, 2020 & 39 & 56 & 0.70 & {$[0.56-0.81]$} & $12.90 \%$ \\
\hline Chettamany, 2020 (VIP) & 26 & 30 & 0.87 & {$[0.69-0.96]$} & $6.60 \%$ \\
\hline Wang, 2020 & 140 & 161 & 0.87 & [0.81-0.92] & $15.00 \%$ \\
\hline Pedrazzoli, 2018 & 50 & 66 & 0.76 & {$[0.64-0.85]$} & $13.10 \%$ \\
\hline Tomeny,2020 & 20 & 25 & 0.80 & {$[0.59-0.93]$} & $7.30 \%$ \\
\hline Collins Timire, 2020 & 44 & 49 & 0.90 & {$[0.78-0.97]$} & $7.80 \%$ \\
\hline Y-Z. Ruan, 2016 & 57 & 73 & 0.78 & {$[0.67-0.87]$} & $13.20 \%$ \\
\hline Random effect model & 463 & 574 & 0.80 & [0.74-0.85] & \\
\hline \multicolumn{6}{|l|}{ Heterogeneity $\left.\right|^{2}=54 \%$} \\
\hline \multicolumn{6}{|c|}{ 3. Pooled proportion of catastrophic cost at $20 \%$ among TB and HIV infected patients } \\
\hline Chittamany, 2020 & 100 & 123 & 0.81 & [0.73-0.88] & $17.80 \%$ \\
\hline Collins Timire, 2020 & 450 & 557 & 0.81 & [0.77-0.84] & $82.20 \%$ \\
\hline Random effect model & 550 & 680 & 0.81 & [0.78-0.84] & \\
\hline \multicolumn{6}{|l|}{ Heterogeneity $\mathrm{I}^{2}=0 \%$} \\
\hline \multicolumn{6}{|c|}{ 4. Pooled proportion of catastrophic cost at $20 \%$ among during active case finding after sub-group analysis } \\
\hline \multicolumn{6}{|l|}{ Inside India } \\
\hline Muniyandi, 2019 & 10 & 108 & 0.09 & {$[0.5-0.16]$} & \\
\hline Shewade, 2018 & 24 & 234 & 0.10 & {$[0.7-0.15]$} & \\
\hline Fixed effect model & 34 & 342 & 0.10 & {$[0.07-0.14]$} & \\
\hline \multicolumn{6}{|l|}{ Heterogeneity $\left.\right|^{2}=0 \%$} \\
\hline \multicolumn{6}{|l|}{ Outside India } \\
\hline Morishita, 2016 & 39 & 108 & 0.36 & {$[0.27-0.46]$} & \\
\hline Suman Chandra Gurung, 2019 & 24 & 39 & 0.61 & {$[0.45-0.77]$} & \\
\hline
\end{tabular}




\begin{tabular}{|c|c|c|c|c|c|}
\hline \multicolumn{6}{|c|}{ 1. Pooled proportion of catastrophic cost at $20 \%$ among drug sensitive } \\
\hline Fixed effect model & 63 & 247 & 0.26 & \multicolumn{2}{|l|}{$[0.25-0.72]$} \\
\hline \multicolumn{6}{|c|}{ 5. Pooled proportion of direct to total cost at catastrophic cost of $20 \%$ among active case finding } \\
\hline Morishita, 2016 & 110.5 & 399 & 0.28 & {$[0.23-0.32]$} & $57.70 \%$ \\
\hline Shewade, 2018 & 12 & 4.5 & 0.80 & $0.28-0.99]$ & $4.90 \%$ \\
\hline Muniyandi, 2019 & 18 & 69 & 0.26 & {$[0.16-0.38]$} & $37.40 \%$ \\
\hline Random effect model & 140.5 & 427.5 & 0.29 & {$[0.20-0.41]$} & \\
\hline \multicolumn{6}{|l|}{ Heterogeneity $\mathrm{I}^{2}=\mathbf{5 5} \%$} \\
\hline \multicolumn{6}{|c|}{ 6. Pooled proportion of direct to total cost at catastrophic cost of $20 \%$ among passive case finding } \\
\hline Morishiita, 2016 & 206 & 535 & 0.39 & {$[0.34-0.43]$} & $33.6 \%$ \\
\hline Shewade, 2018 & 26.9 & 28.4 & 0.94 & $0.98-0.90]$ & $4.2 \%$ \\
\hline Muniyandi, 2019 & 79 & 227 & 0.35 & {$[0.29-0.41]$} & $30.1 \%$ \\
\hline Suman Chandra Gurung, 2019 & 131.74 & 325.3 & 0.45 & {$[0.35-0.46]$} & $32.1 \%$ \\
\hline Random effect model & 443.64 & 1115.7 & 0.37 & {$[0.31-0.42]$} & \\
\hline \multicolumn{6}{|l|}{ Heterogeneity $\left.\right|^{2}=0 \%$} \\
\hline \multicolumn{6}{|c|}{ 7. Pooled proportion of the direct cost to the total cost } \\
\hline Wingfield, 2014 & 392 & 961 & 0.41 & {$[0.38-0.44]$} & $8.1 \%$ \\
\hline Muttamba, 2020 & 400.48 & 556.58 & 0.72 & {$[0.68-0.76]$} & $8.0 \%$ \\
\hline Gadallah, 2018 & 89 & 198 & 0.45 & {$[0.38-0.52]$} & $7.9 \%$ \\
\hline Shewade, 2018 & 18.1 & 19.5 & 0.93 & {$[0.70-0.99]$} & $3.9 \%$ \\
\hline Muniyandi, 2020 & 108.48 & 451.35 & 0.24 & {$[0.20-0.28]$} & $8.0 \%$ \\
\hline Prasanna, 2018 & 77.32 & 234.1 & 0.33 & {$[0.27-0.39]$} & $7.9 \%$ \\
\hline Viney, 2019 & 1588.43 & 2585.54 & 0.61 & {$[0.60-0.63]$} & $8.1 \%$ \\
\hline Wang, 2020 & 6316 & 8266 & 0.76 & {$[0.75-0.77]$} & $8.1 \%$ \\
\hline Xu, 2019 & 769.2 & 839.6 & 0.92 & {$[0.90-0.93]$} & $7.9 \%$ \\
\hline Ikram, 2020 & 292.76 & 843.12 & 0.35 & {$[0.32-0.38]$} & $8.1 \%$ \\
\hline Nhung et al., 2018 & 736 & 1314 & 0.56 & {$[0.53-0.59]$} & $8.1 \%$ \\
\hline Suman Chandra Gurung, 2019 & 79.4 & 286.4 & 0.28 & {$[0.23-0.33]$} & $7.9 \%$ \\
\hline Collins Timire, 2020 & 620.97 & 1360 & 0.46 & {$[0.43-0.48]$} & $8.1 \%$ \\
\hline Random effect model & 10867.2 & 16555.2 & 0.55 & {$[0.43-0.66]$} & \\
\hline \multicolumn{6}{|l|}{ Heterogeneity $\mathrm{I}^{2}=96 \%$} \\
\hline \multicolumn{6}{|c|}{ 8. Pooled proportion of Catastrophic Health Expenditure at $10 \%$} \\
\hline Lu, 2020 & 132 & 248 & 0.53 & {$[0.47-0.60]$} & $26.80 \%$ \\
\hline Muttamba, 2020 & 567 & 1155 & 0.49 & {$[0.46-0.52]$} & $73.20 \%$ \\
\hline Random effect model & 699 & 1403 & 0.5 & [0.47-0.54] & \\
\hline \multicolumn{6}{|c|}{ 9. Catastrophic Health Expenditure at $10 \%$ \& Capacity to Pay at $40 \%$} \\
\hline Wang, 2020 & 110 & 161 & 0.68 & {$[0.61-0.5]$} & $71.30 \%$ \\
\hline Y-Z Ruan, 2016 & 54 & 73 & 0.74 & {$[0.62-0.84]$} & $28.70 \%$ \\
\hline Random effect model & 164 & 234 & 0.7 & {$[0.64-0.76]$} & \\
\hline
\end{tabular}

\section{Figures}




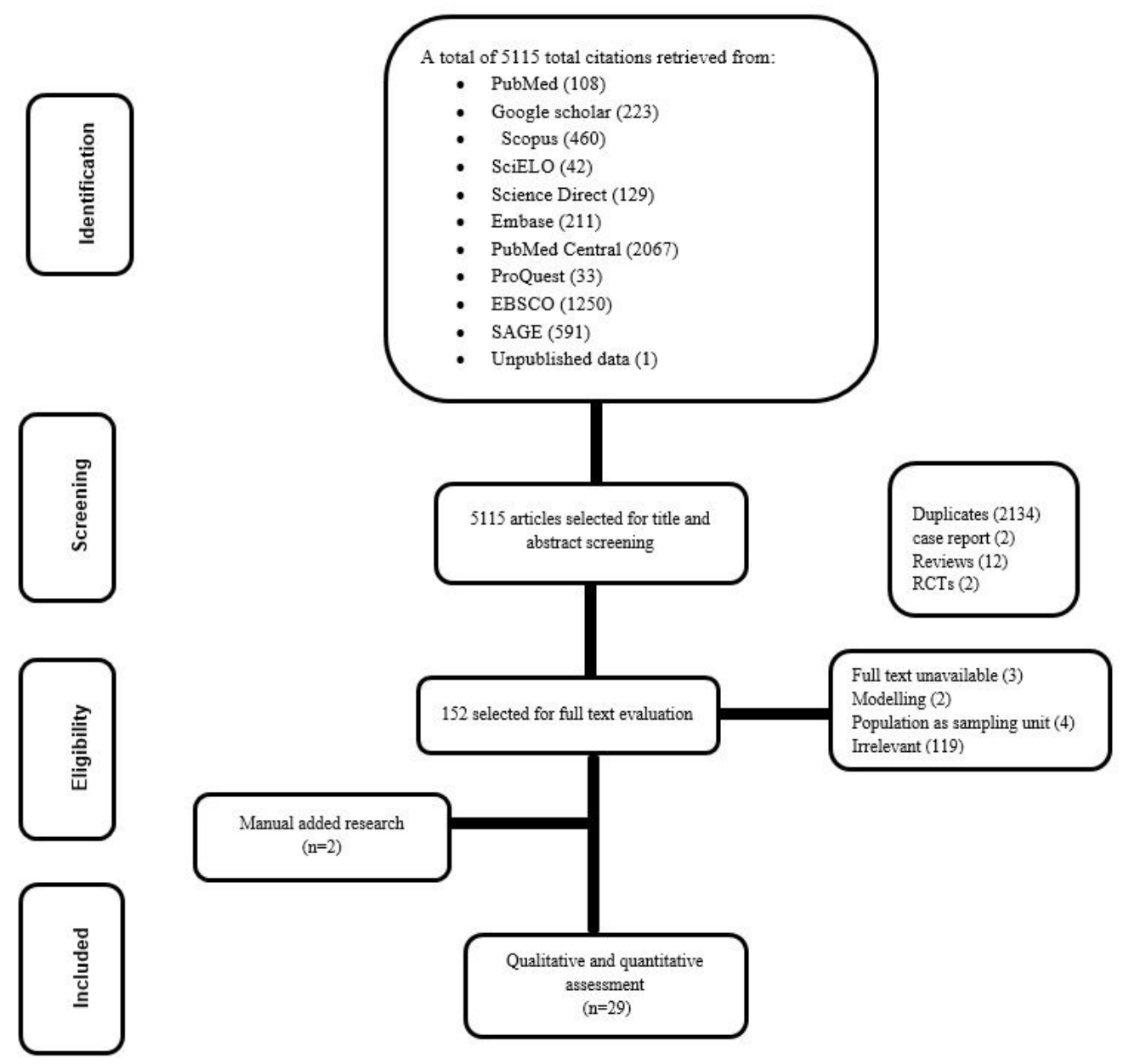

Figure 1

PRISMA flow-charts of studies included in meta-analysis of catastrophic cost/expenditure among patients with tuberculosis.

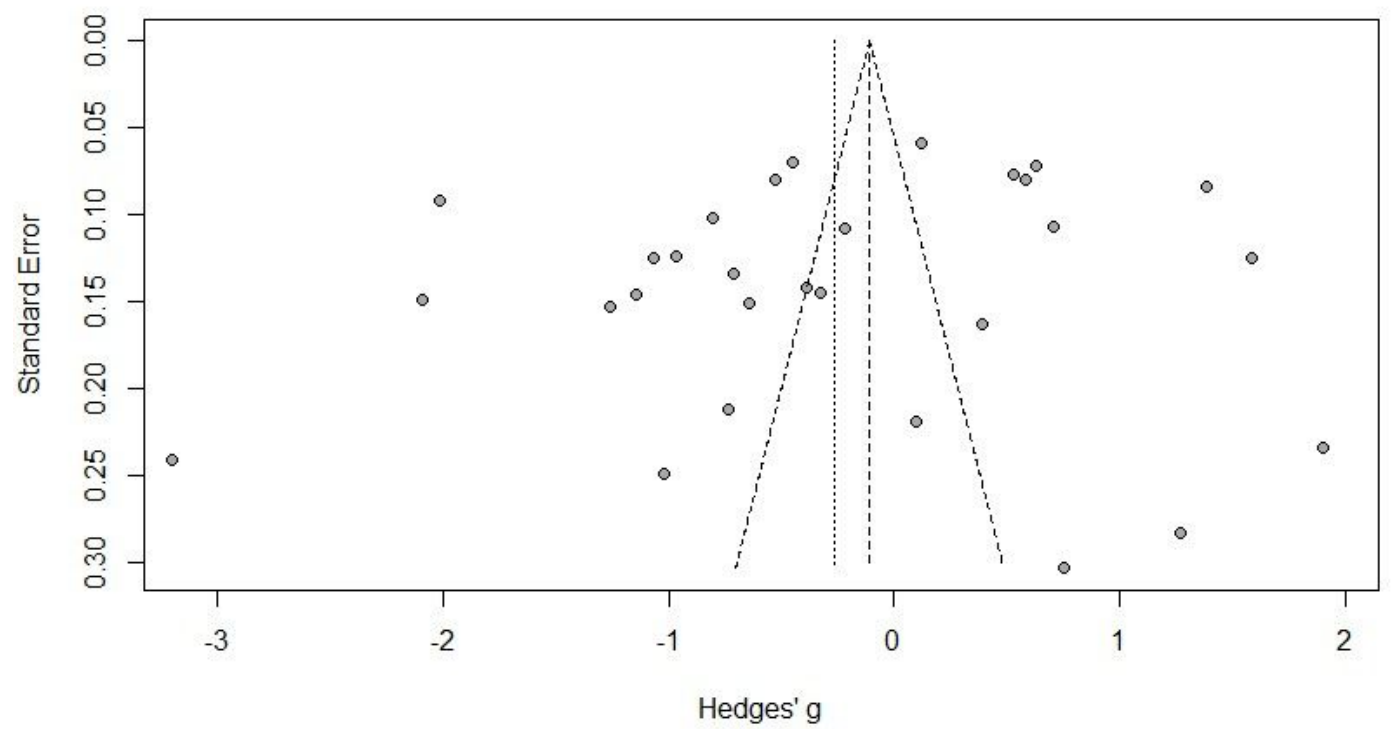

Figure 2

Funnel plot of studies included in estimation of the proportion tuberculosis patients facing catastrophic cost. 


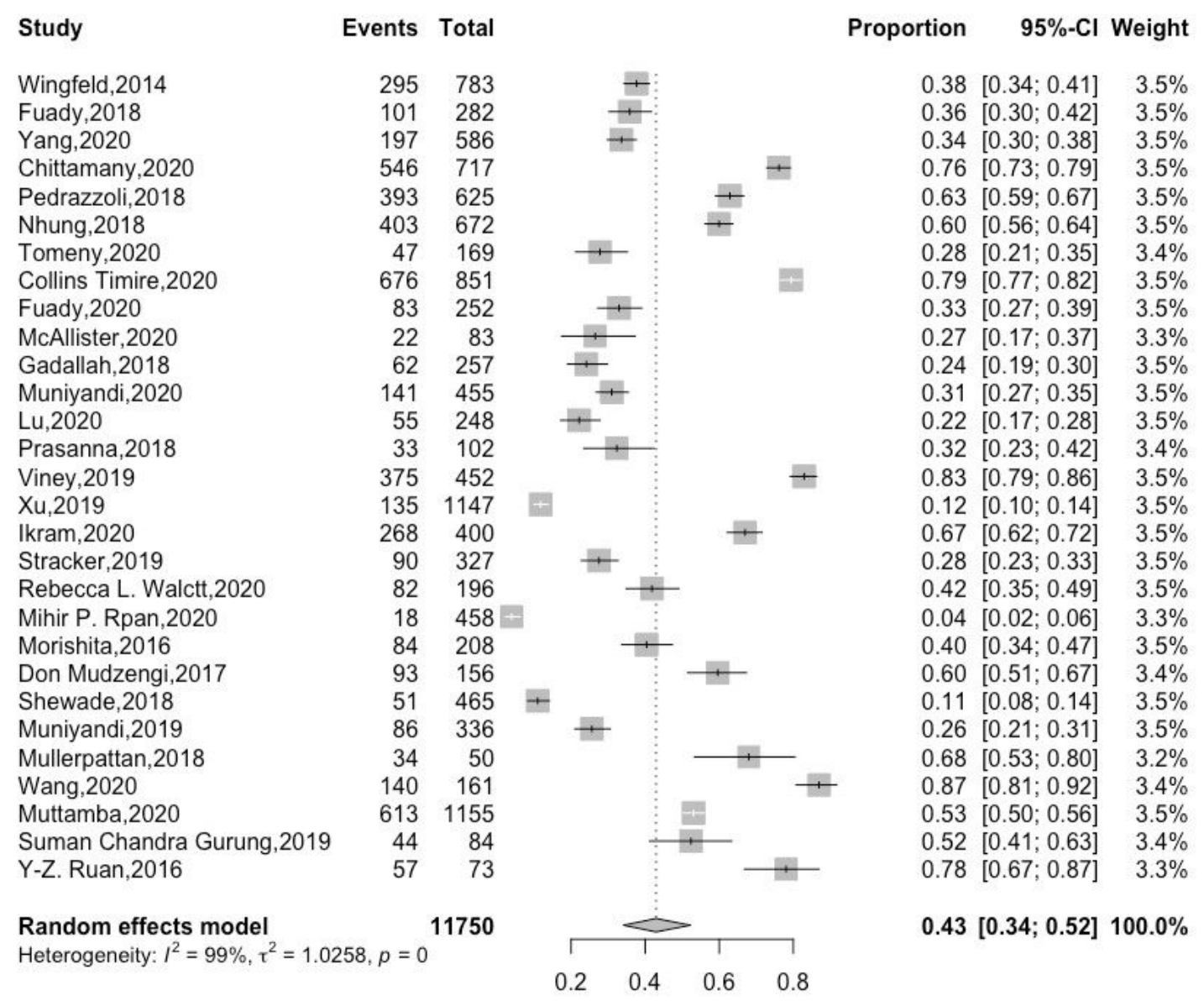

Figure 3

Pooled proportion of catastrophic cost at $20 \%$ 